- 34- 九 州霆会誌・第 24 巻第 1 号 (1970)

鹿児島县種子島㕕田遺跡上り出土せる弥生式時代人歯牙の

人 類 学 的研 究

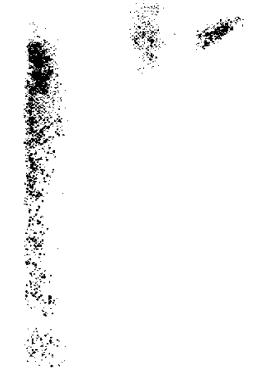

九州霜科大学口腔解剖学教室 (主任 : 山田 博教授)

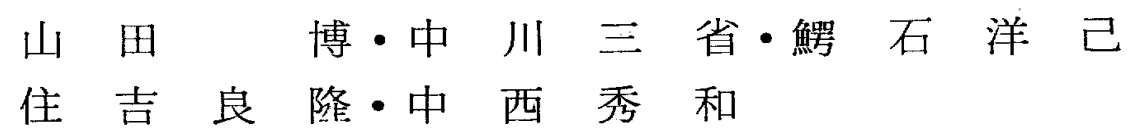

（昭和44年 9 月19日受理）

\title{
ANTHROPOLOGICAL STUDIES ON THE TEETH OF THE PREHISTORIC YAYOI-ANCIENTS EXCAVATED FROM THE HIROTA SITE, TANEGA- SHIMA, KAGOSHIMA-PREFECTURE
}

By

\author{
Hiroshi YAMADA, Kazumi NAKAGAWA, Hiromi WANIISHI, \\ Yoshitaka SUMIYOSHI and Hidekazu NAKANISHI \\ Department of Oral Anatomy (Director: Prof. Hiroshi YAMADA) \\ Kyushu Dental College, Kitakyushu, Japan
}

Measurements and morphological studies were conducted on the teeth of Yayoi ancients that had been excavated at the Hirota site, Tanegashima island, Kagoshima Prefecture. The study was mainly directed to detect morphological features of the teeth of these ancients, to compare the findings with those of modern Japanese counterpart and to get some information of the possible age change of the teeth by the aid of anthropological or phylogentical concepts.

Principal points of interest were summarized as follows.

1. The size of teeth from the ancients was larger in their length, especially in length of root part. In contrast to this, breadth of tooth crown was smaller than that of modern Japanese tooth crown. Such elongation of the tooth root should be interpreted in terms of an adaptation of tooth to coarser and harder diets taken at the time which would require the tooth to develop greater stability in the socket of jaw, and hence the longer root.

2. The presence of blind foramen, incisura obliqua and caninization, all of which are regarded as signs of retrogression in the upper lateral incisor could be observed less frequently than in modern Japanese counterpart. Also less frequent was the occurrence of the shovel-shaped incisors, especially in upper central incisors, in the ancients men as compared with the dentition of modern Japanese.

3. In view of the groove type of occlusal surface in the upper premolars and the manner in which the root was branched, it was suggested that these teeth, especially the 1st premolar tended to show relatively primitive shape as compared to modern Japanese.

4. With lower premolars, the way in which the cusps and the occlusal grooves occurred 
in the teeth of ancients suggested an age change of these teeth which was more marked in the 2nd rather than in the 1st premolar.

5. With upper molars, the 1st molar in the ancients showed with no exception 4 completely formed cusps and the 2nd molar was also quadruply cusped in the majority of cases, suggesting that they kept more primitive form as compared to modern Japanese dentition.

6. With regard to occurrence of cusp number and the type of occlusal groove in lower molar of the ancients, the most frequent was so-called Dryopithecus Pattern ( $\mathrm{Y}_{5}$ ) in the 1st molar where 5 cusps and $\mathrm{Y}$-shape groove were common, and in the 2nd and 3rd molars the groove shapes $+_{4}$ and $\mathrm{X}_{4}$ were respectively most predominant, showing little, if ever, deviation from patterns of modern Japanese dentition. No significant variation was noticed in number and shape of the tooth root, and the Ist and 2nd molars had almost all 2 roots. Occurrence of supernumerary tubercle such as Protostylid, 6th cusp and 7th cusp was very rare.

Conclusions were drawn form the above findings that the lower jaw teeth in Hirota ancients showed no significant deviation from comparable teeth of modern Japanese in every morphological traits examined, while teeth from upper jaw of Hirota ancients deviated in some way or other from those of modern Japaness.

\section{目次}

I . 緒 言

II．調查資料ならびに調查項目と方法

III. 調查成績

1. 咬耗度ならびにう歯の出現状態

2. 歯の計測成績

3. 歯牙形態の観察成績

( I ) 前歯部

(2) 小曰荬部

(3) 上頢大臼歯部

(4) 下顎大且歯部

IV. 総括ならびに考察

V. 結 論

参考文献

\section{I . 緒言}

わが国の先史時代人の歯に関する研究は縄文式時代人 あるいは弥生式時代人についての研究等の中で一部報告 がなされているが, 発堀人骨に付属している歯を一地域 の集団として総合的に詳細に調査されたものはきわめて 少なく, 大野1)の三津弥生式時代人および讃井2) の土井 ケ浜弥生式時代人についての歯の研究がみられ，はなは だ興味ある見解を述べられている，また最近では藤原等 7) は田能遺跡出土の弥生式時代人の函牙についての調査
報告を行なっている.

われわれは今回鹿児島県種子島広田遺跡より発堀せら れた弥生式時代人（弥生中期）の霜牙についてその計測 ならびに観察を行ない，弥生時代人の歯の形態的特徴を 知るととを目的として調查を行なった。 また菌というも のが硬組織器官であるため，長年月を経過した後でもそ の形態が比較的によく保存されていることから, 人類学 的に現代人の歯牙との比較上有力な手がかりとなるもの である．したがって現代日本人の雬牙形態と比較するこ とにより, 人類学的にあるいは形態学的に雪牙形質の時 代的変化の推移疌把握しようとしてての研究を行なった あのである.

\section{II . 調查資料ならびに調查項目と方法}

本研究に用いた菌牙は九州大学医学部解剖学教室所蔵 の1957年より1959年にわたって広田遺跡より発掘された 頭蓋骨に付随しているものおよび当遺跡でそれらの人骨 の付近㳻逸していた遊離歯牙である。これらの蒾牙に ついてはその部位が判別確認できるもので，しかむ完全 に計測ならびに観察可能なもののみを選択した，性別の 判別ができるものは少ないため, 男女一緒にして取り扱 かった。 また左右側の区別も可能ではあるが，そうする 之例数が非常に少なくなる茵種があるので, 計測値の場 合のみは左右側の区別を行なわずにまとめて調査した。 各歯牙別の調查例数は表 Iに示す通りである. 

広田遺跡弥生式時代人雪牙調査総数（永久茵）

\begin{tabular}{|c|c|c|c|c|c|c|c|c|c|c|c|c|c|c|c|c|c|}
\hline & & \multicolumn{4}{|c|}{ 上 } & \multicolumn{4}{|c|}{ 顎 } & \multicolumn{4}{|c|}{ 下 } & \multicolumn{4}{|c|}{ 顎 } \\
\hline & & $I_{1}$ & $\mathrm{I}_{2}$ & $\mathrm{C}$ & $P_{1}$ & $\mathrm{P}_{2}$ & $\mathbf{M}_{1}$ & $\mathrm{M}_{2}$ & $\mathbf{M}_{3}$ & $\mathrm{I}_{1}$ & $\mathrm{I}_{2}$ & C & $P_{1}$ & $\mathbf{P}_{2}$ & $\mathbf{M}_{1}$ & $\mathbf{M}_{2}$ & $\mathbf{M}_{\mathbf{3}}$ \\
\hline \multirow{3}{*}{ 古 } & $\mathbf{R}$ & 18 & 13 & 15 & 20 & 18 & 19 & 19 & 12 & 18 & 21 & 21 & 23 & 22 & 16 & 18 & 11 \\
\hline & $\mathbf{L}$ & 18 & 12 & 17 & 19 & 20 & 19 & 19 & 11 & 19 & 21 & 20 & 20 & 18 & 17 & 21 & 11 \\
\hline & 計 & 36 & 25 & 32 & 39 & 38 & 38 & 38 & 23 & 37 & 42 & 41 & 43 & 40 & 33 & 39 & 22 \\
\hline \multirow{3}{*}{ 우 } & $\mathbf{R}$ & 8 & 8 & 10 & 15 & 15 & 15 & 13 & 7 & 13 & 17 & 17 & 17 & 11 & 15 & 18 & 8 \\
\hline & $\mathrm{L}$ & 10 & 7 & 11 & 15 & 14 & 15 & 15 & 6 & 13 & 15 & 17 & 16 & 18 & 14 & 21 & 10 \\
\hline & 計 & 18 & 15 & 21 & 30 & 29 & 30 & 28 & 13 & 26 & 32 & 34 & 33 & 29 & 29 & 39 & 18 \\
\hline \multirow{3}{*}{$\begin{array}{l}\text { 不 } \\
\text { 明 }\end{array}$} & $\mathbf{R}$ & 30 & 10 & 17 & 31 & 25 & 34 & 26 & 24 & 25 & 18 & 39 & 37 & 38 & 39 & 33 & 20 \\
\hline & $\mathrm{L}$ & 38 & 12 & 16 & 27 & 21 & 19 & 29 & 24 & 27 & 20 & 34 & 31 & 38 & 39 & 33 & 19 \\
\hline & 計 & 68 & 22 & 33 & 58 & 46 & 53 & 55 & 48 & 52 & 38 & 73 & 68 & 76 & 78 & 65 & 39 \\
\hline \multirow{3}{*}{$\begin{array}{l}\text { 総 } \\
\text { 数 }\end{array}$} & $\mathbf{R}$ & 56 & 31 & 42 & 66 & 58 & 68 & 58 & 43 & 56 & 57 & 77 & 77 & 71 & 70 & 69 & 39 \\
\hline & $\mathbf{L}$ & 66 & 31 & 44 & 61 & 55 & 53 & 63 & 41 & 59 & 56 & 71 & 67 & 74 & 70 & 75 & 40 \\
\hline & 計 & 122 & 62 & 86 & 127 & 113 & 121 & 121 & 84 & 115 & 113 & 148 & 144 & 145 & 140 & 144 & 79 \\
\hline
\end{tabular}

咬籷度については Martin 25)の分類法にしたがって0 度より 4 度までに分類し，前歯部では切縁と舌側面を曰 蒾部では咬合面を主たる対象とした。

茵の計測は藤田6)の計测規準に準拠し，計測部位は歯 冠の長さ，幅招よび厚さと歯根の長さならびに歯の全長 である.さらにそれら計測值相互間の指数值については 歯冠幅厚指数および冠根指数を算出して検討した。尚計 測に当っては歯の咬籷によってその計測值が変異するた め, 咬籷度 2 度以上のものは除外した. 以上の計測值扔よ び指数值については各歯牙別に標本平均值 $(\mathbf{M})$ ，不偏分 散推定值（ $\left.\mathbf{u}^{2}\right)$ を算出した。また比較の対象としては同 時代人のものとして大野1）の三津弥生式人打よび讃井2) の土井ケ浜弥生式人を，現代日本人では藤田宗次3) の成 績を選んだ。乙の場合 $5 \%$ の危険率をもって有意の差之 した。

観察成績は下記のごとき各項目について調査した。 前歯部

シャベル型切蒾については Hrdlička 26)（1920）の分 類法にしたがって次の四型に分けた。（1）辺縁隆線は 強く発達し舌側面窝の宿凹の著しいもの，乙れを Shovel-Shape (S), (2) 辺縁隆線は強く発達しているが 舌側面䆟はやや浅いむの, Semi-Shovel (SS), (3) 辺 縁隆線は明瞭にその存在が認められるが前者ほどには明 らかでないもの, Trace-Shovel (TR), (4) 辺縁隆線 および舌側面窩はほとんど存在しないかまた認められて あきわめて弱いむの, No-Shovel (NO) である.

その他基底結節の発達状態, 棘突起, 盲孔および斜切
痕の出現状態ならびに側切歯の犬歯化の傾向について調 查した

\section{小囦画部}

上下顎とも咬合面裂溝形態については著者等8)(1964) が行なった分類方式にしたがって図1および 2 に示す。

図1上顎小臼荬の咬合面の溝型
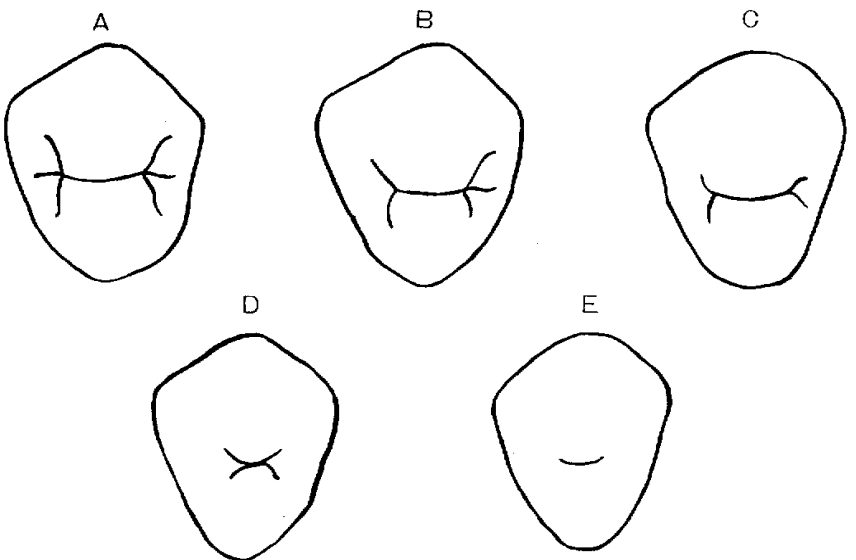

図 2 下顎小臼歯の咬合面の溝型
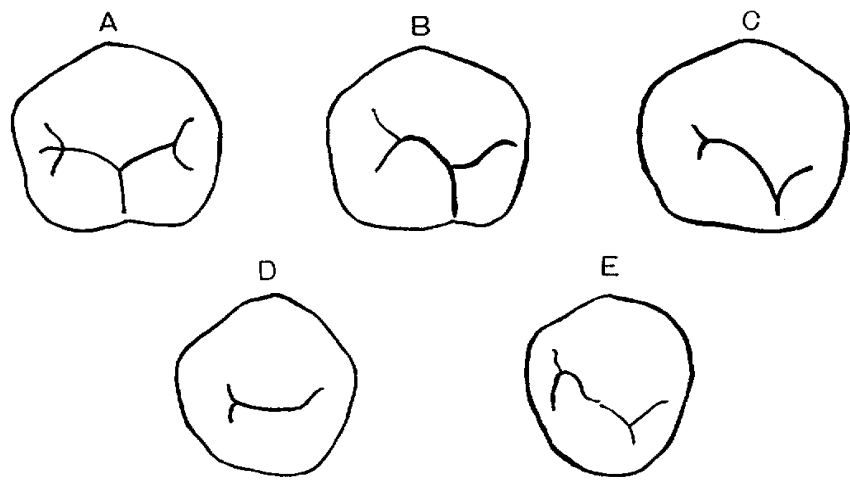
ごよく，それぞれA型より $\mathrm{E}$ 型までの五段階に分類し た. 下顎小曰幽の咬頭型も同じく著者等8) の(1964)の分 類方式にしたがい，2-型(頓側咬頭に対して舌側咬頭が 著しく発達の墨いもの），2 型（頓舌両咬頭が ともによ く発達しているもの），3一型（煩側咬頭に対して舌側に 2 コの咬頭があるが，その中遠心のものが著しく発達の 悪いむの), 3 型（煩側に1コ舌側にほぼ同大の 2 コの 咬頭を有するもの）の四段階に分類した。

その他上顩では介在結節ならびに米根数について，下 顎では咬合面の連合隆線の状態について調査した。

上顎大兒蒾部

図 3 上顎大巨䨑の咬頭退化の各型

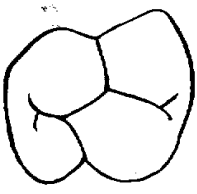

4

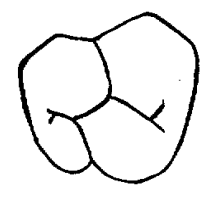

$4-$

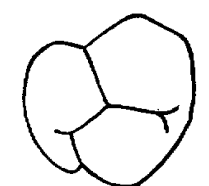

$3+$

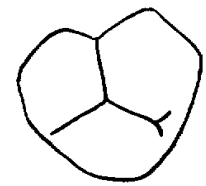

3
下澦大曰歯部

咬頭数ならびに咬合面の裂溝形態について調查を行な ったが，交合面溝の形態に関しては Gregory 等が現代 人の下顎大臼蒾の基本的な咬合面形態としている Dryopithecus Pattern すなわちY型，さらには Hellman あるいは J $\phi$ rgensen ${ }^{12)}$ による十型， X 型の三型に分類 し(図 5)，また咬頭数とてれら满型との関連性につい てはY $5, \mathrm{Y}_{4},+_{5},+_{4}, \mathrm{X}_{5}$, および $\mathrm{X}_{4}$ というふうに 分類した。

次に歯根数乙桶状根の出現状態について調查した。 た過剩結節については Protostylid, 第 6 咬頭㧍よび第 7 咬頭の出現頻度を調査した。

図 5 下顎大臼歯咬合面の溝型
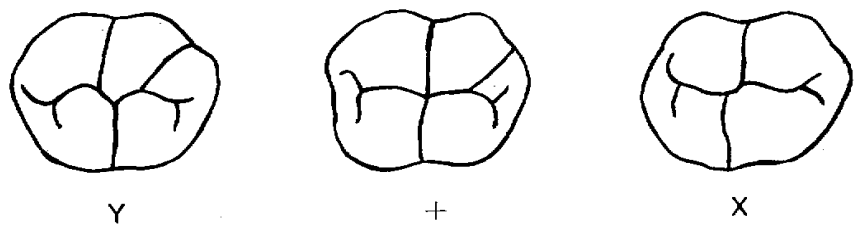

図 4 上顎大曰歯蒾冠の近遠心的圧平の各型
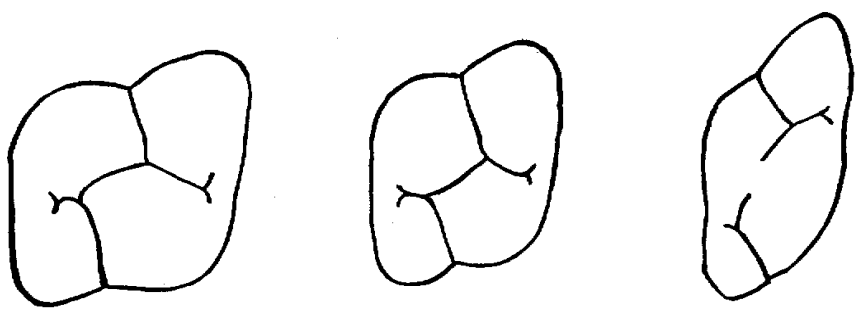

咬頭の形態については Dahlberg 20)(1951)の分類法に もとずき図 3 のどとく 4,4 - 3 +扰よび 3 の四型に 分類した。㐘冠の近遠心的圧平の状態については図 4 の ごとく+，士抢よび一の三段階に分類した。 その他崡根 数ならびに過剩結節（カラベリ一結節, 曰旁結節, 臼後 結節）について調查した。

\section{1. 咬粍ならびにう歯の出現状態}

広田弥生式人のう歯出現状況は表 2 のごとく各歯別に それぞれ異なっているが，総体的には約 $8 \%$ で大正齿特 に下顎に多く，前䨑部に括いてはきわめて少ない，ての 調査では顎骨より遊離している単独の歯についても, そ れらを含めて各歯別にその出現頻度を調べたもので, 各 個体別についてのう歯保有状況は不明であるため, やや 正確度を欠ぐ点は認められるが，表了にみられるごとく 土井ケ浜执よび王津の各弥生式人に比べて少なく，小金 井の古墳時代人椄るいは清野の津雲石器時代人に比べる と多くなっている。また現代人に比べるよかなり少なく なっている。一般に広田弥生式人は現代人に比べてう菡 の発生率は少ないように考えられる。

表 2 広田遺跡弥生式人の蔐崡出現状況

\begin{tabular}{|c|c|c|c|c|c|c|c|c|c|c|c|c|}
\hline & & $I_{1}$ & I $_{2}$ & $\mathrm{C}$ & $P_{1}$ & $\mathbf{P}_{2}$ & $\mathbf{M}_{1}$ & $\mathrm{M}_{2}$ & $\mathbf{M}_{3}$ & 計 & 合 & 計 \\
\hline \multirow{2}{*}{ 調査歯数 } & 上 & 119 & 61 & 85 & 123 & 111 & 121 & 121 & 84 & 825 & \multirow{2}{*}{\multicolumn{2}{|c|}{1857}} \\
\hline & 下 & 111 & 113 & 149 & 147 & 151 & 139 & 143 & 79 & 1032 & & \\
\hline \multirow{2}{*}{ 䶖两 歯 数 } & 上 & 1 & 3 & 2 & 4 & 6 & 23 & 10 & 12 & 61 & \multirow{2}{*}{\multicolumn{2}{|c|}{149}} \\
\hline & 下 & 0 & 0 & 0 & 11 & 18 & 21 & 15 & 23 & 88 & & \\
\hline \multirow{2}{*}{$\%$} & 上 & 0.8 & 4.9 & 2.4 & 3.3 & 5.4 & 19.0 & 8.3 & 14.3 & 7.4 & \multirow{2}{*}{\multicolumn{2}{|c|}{8.0}} \\
\hline & 下 & 0 & 0 & 0 & 7.5 & 11.9 & 15. 1 & 10.5 & 29.1 & 8.5 & & \\
\hline
\end{tabular}




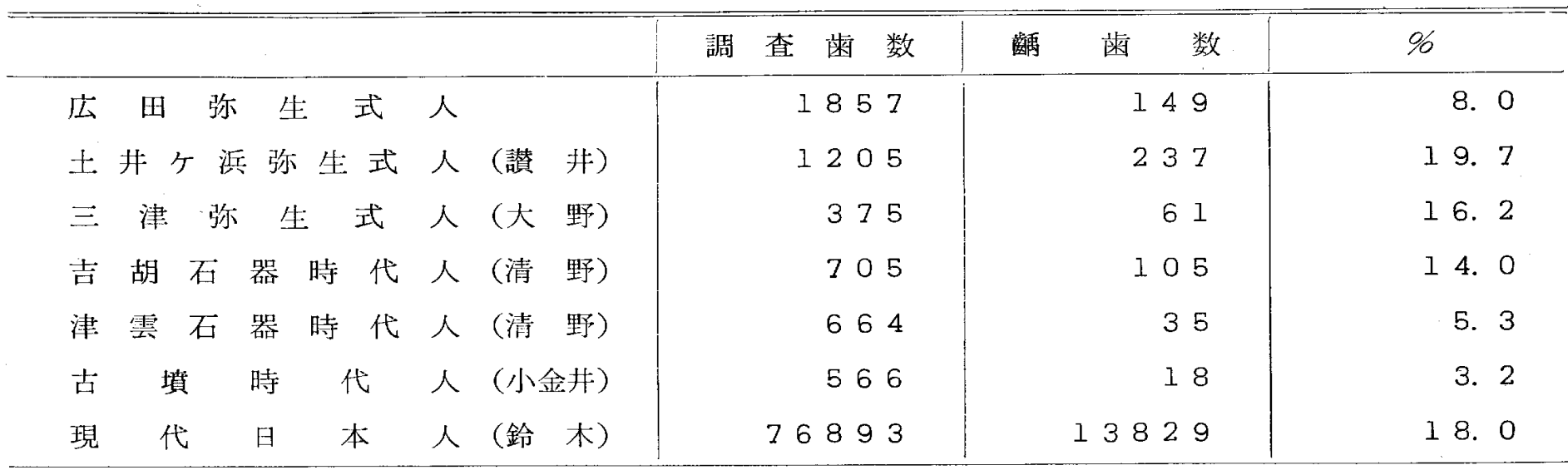

表4広田遺跡弥生式時代人の咬耗度

\begin{tabular}{|c|c|c|c|c|c|c|c|c|c|c|c|}
\hline $\begin{array}{l}\text { 校 } \\
\text { 檥 } \\
\text { 度 }\end{array}$ & $\begin{array}{l}\text { 卡 } \\
\text { 別 }\end{array}$ & 歯別 & $I_{1}$ & $\mathrm{I}_{2}$ & $C$ & $\mathbf{P}_{1}$ & $\mathrm{P}_{2}$ & $\mathrm{M}_{1}$ & $\mathbf{M}_{2}$ & $\mathrm{M3}$ & 計 \\
\hline \multirow{4}{*}{$0 \sim 1$} & 上 & $\mathbf{N}$ & 34 & 18 & 28 & 45 & 32 & 16 & 23 & 26 & 222 \\
\hline & 顎 & $\%$ & 27.8 & 28.6 & 30.8 & 36.0 & 28.8 & 13.1 & 19.0 & 31.7 & 26.5 \\
\hline & 下 & $\mathbf{N}$ & 36 & 42 & 46 & 22 & 33 & 10 & 9 & 21 & 219 \\
\hline & 顎 & $\mathscr{\%}$ & 30.8 & 36.8 & 32.2 & 15.4 & 21.8 & 7.2 & 6.2 & 27.3 & 21.4 \\
\hline \multirow{4}{*}{2} & 上: & $\mathbf{N}$ & 44 & 21 & 34 & 41 & 38 & 46 & 53 & 31 & 308 \\
\hline & 顎 & $\%$ & 36.1 & 33.3 & 37.4 & 32.8 & 34.2 & 37.7 & 43.8 & 37.8 & 36.8 \\
\hline & 下 & $\mathbf{N}$ & 41 & 32 & 44 & 57 & 48 & 69 & 70 & 30 & 391 \\
\hline & 顎 & $\%$ & 35.0 & 28.1 & 30.8 & 39.9 & 33. 1 & 49.6 & 48.3 & 39.0 & 38.2 \\
\hline \multirow{4}{*}{3} & 上: & $\mathrm{N}$ & 30 & 11 & 16 & 23 & 27 & 41 & 35 & 19 & 202 \\
\hline & 顎 & $\%$ & 24.6 & 17.5 & 17.6 & 18.4 & 24.3 & 33.6 & 28.9 & 23. 2 & 24.1 \\
\hline & 下 & $\mathbf{N}$ & 22 & 23 & 34 & 44 & 35 & 40 & 41 & 17 & 256 \\
\hline & 顎 & $\%$ & 18.8 & 20.2 & 23.8 & 30.8 & 24.1 & 28.8 & 28.3 & 22.1 & 25.0 \\
\hline \multirow{4}{*}{4} & 上 & $\mathbf{N}$ & 14 & 13 & 13 & 16 & 14 & 19 & 10 & 6 & 105 \\
\hline & 薟 & $\%$ & 11.5 & 20.6 & 14.3 & 128 & 12.6 & 15.6 & 8.3 & 7.3 & 12.5 \\
\hline & 下 & $\mathbf{N}$ & 18 & 17 & 19 & 20 & 29 & 20 & 25 & 9 & 157 \\
\hline & 顎 & 96 & 15.4 & 14.9 & 13. 3 & 14.0 & 20.0 & 14.4 & 17.2 & 11.7 & 15.3 \\
\hline 総 & 上 & 顎 & 122 & 63 & 91 & 125 & 111 & 122 & 121 & 82 & 837 \\
\hline 計 & 下 & 顎 & 117 & 114 & 143 & 143 & 145 & 139 & 145 & 77 & 1023 \\
\hline
\end{tabular}

交粍に関しては表 4 のでとく0〜 I度すなわち咬粍の ほとんどない雪は上顎26.5\%, 下顎21.4\%で，2〜3 度 が全体の60\%以上を示して最も多く, 咬籷の著しい4度 のあのは上顎で $12.5 \%$ ，下顎で15.3\%を示している。 そ の年令構成が不明なためはっきりしたととはいえない
が，同じ咬粍度の歯でも一般に現代人よりもやや若年層 ではないかと考えられることから，咬粍はやや進んでい ると思われる。讃井の土井ヶ浜弥生式人では前爾部では 3 度が, 臼蒾部では $0 〜 1$ 度が最も多いが, 広田弥生式 人では前蒾部では 2 度次いで $0 〜 1$ 度, 臼歯部では 2 度 
表 5

粜 冠

長五

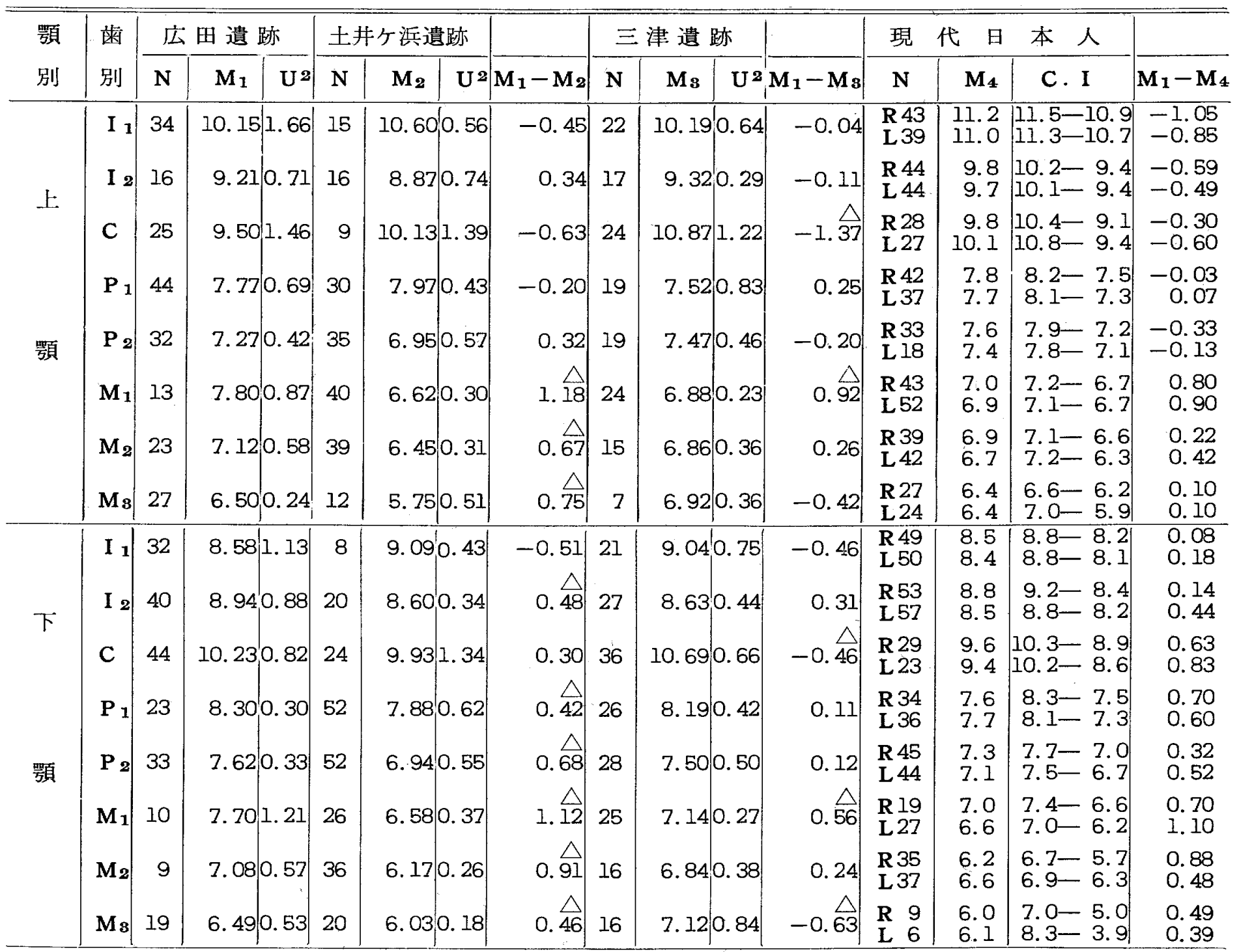

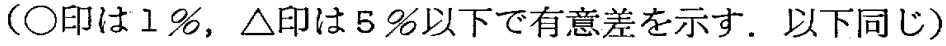

が最も多くなっている，これらの違いは勿論その年令層 や食生活などの差異に基因しているものであろう.

\section{2. 歯の計测成績}

\section{䨑冠の長さ}

表 5 のごとく土井ケ浜弥生式人に比べると一般に大き く，特に上下顎大臼畨，下顎側切歯执よび小四歯では有 意差を示している。三津弥生式人との比較では上下顎第 I大田歯は大きく，上下顎犬㐘および下顎第 3 大臼㐘は 小さいが，その他の柬牙ではあまり差はない，現代日本 人との比較では上顎では一般に短かく，特に前崡部で著 明である。下頡では逆にやや長いようである。

\section{歯根の長さ}

表 6 のごとく土井ヶ浜弥生式人に比べると上顎犬歯, 上顎第 2 小曰霜および下顎側切菌は小さいが，その他の 米についてはあまり差は認められない，三津弥生式人に
比べると全般的に小さく，特に上顎犬歯と小田ならび に上顎第 1 大臼歯は有意差を示している。しかし現代日 本人に比較すると大きい.

歯の全長

表 7 に示すごとく土井ヶ浜弥生式人に比べると上頡第

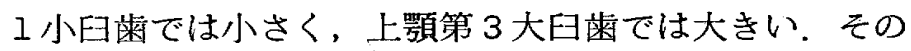
他の歯牙では差異を認めない，三津弥生式人に比べると 小さいが特に上下顎犬歯および上顎第 2 小目歯では著明 である，現代日本人に比べるとやや大きい．

\section{㐘冠の幅}

表 8 に見られるごよく土井ヶ浜および三津弥生式人に 比べて全般的にかなり小さく，現代日本人に比へても小 さい.

\section{㐘冠の厚さ}

表 9 亿示すごとく土井ヶ浜弥生式人よりもやや小さ 


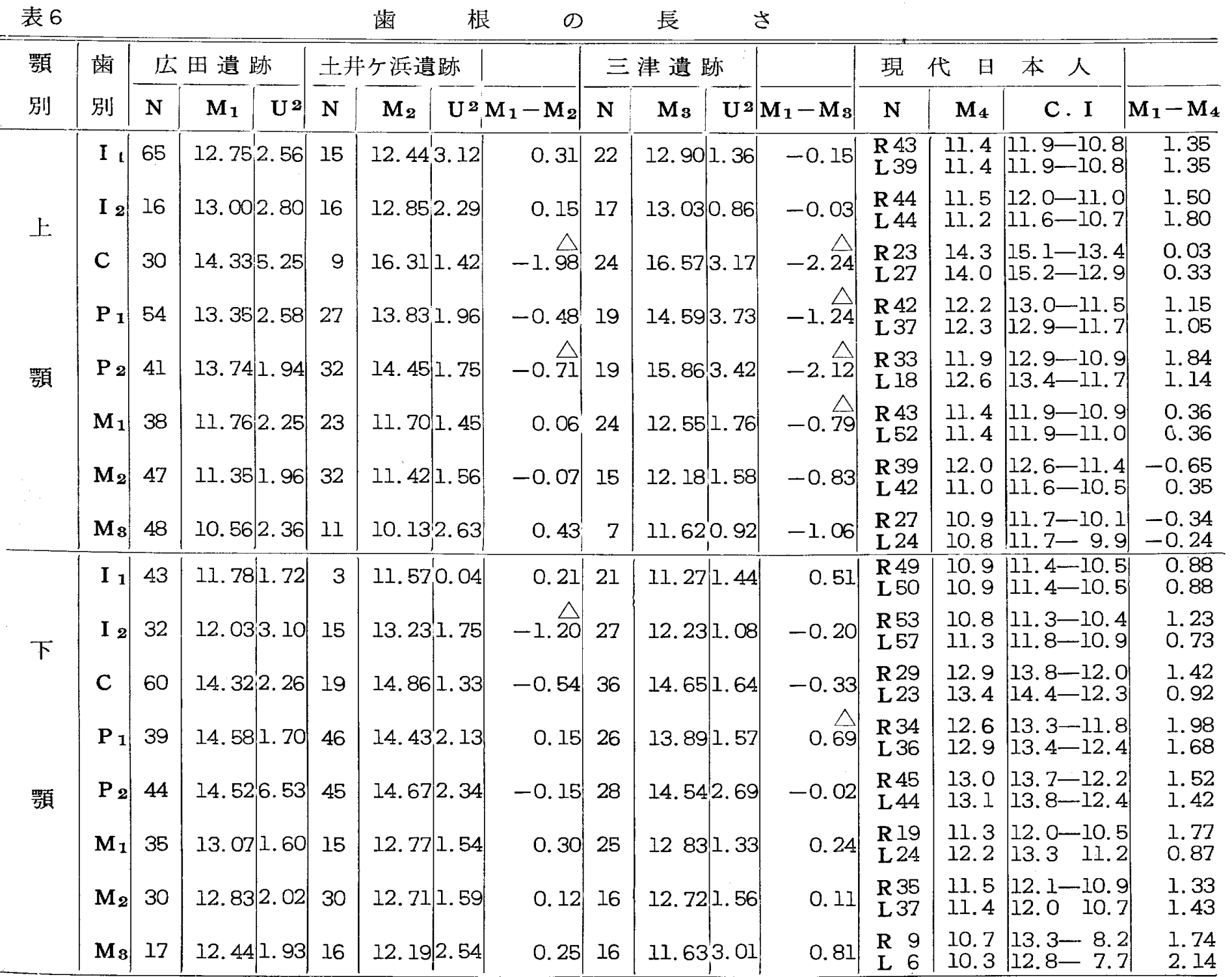

表 7

歯

の 全 長

\begin{tabular}{|c|c|c|c|c|c|c|c|c|c|c|c|c|c|c|c|c|}
\hline \multirow{2}{*}{$\begin{array}{l}\text { 顎 } \\
\text { 別 }\end{array}$} & \multirow{2}{*}{$\begin{array}{l}\text { 歯 } \\
\text { 別 }\end{array}$} & \multicolumn{3}{|c|}{ 広田遺 跡 } & \multicolumn{3}{|c|}{ 土开ヶ浜遺跡 } & & \multicolumn{3}{|c|}{ 三津 遺 跡 } & & \multicolumn{3}{|c|}{ 現代日本人 } & \multirow[b]{2}{*}{$\mathbf{M}_{1}-\mathbf{M}_{4}$} \\
\hline & & $\mathrm{N}$ & $\mathbf{M}_{1}$ & $\mathrm{U}^{2}$ & $\mathbf{N}$ & $\mathbf{M}_{2}$ & $\mathrm{U}^{2}$ & $\mathbf{M}_{\mathbf{1}}-\mathbf{M}_{\mathbf{2}}$ & $\mathbf{N}$ & Ms & $\mathrm{U}^{2}$ & $\left|M_{1}-M_{3}\right|$ & $\mathbf{N}$ & $\mathbf{M}_{4}$ & C. I & \\
\hline \multirow{4}{*}{ L } & $I_{1}$ & 18 & 23.33 & 2.62 & 15 & 23.04 & 1.50 & $0.29^{\prime}$ & 22 & 23. 15 & 3.47 & 0.18 & $\begin{array}{l}\mathrm{R} 43 \\
\mathrm{~L} 39\end{array}$ & $\begin{array}{l}22.5 \\
22.3\end{array}$ & $\mid \begin{array}{l}23.2-21.9 \\
23.0-21.7\end{array}$ & \begin{tabular}{|l|}
0.83 \\
1.03
\end{tabular} \\
\hline & $I_{2}$ & 5 & & 3. 30 & 16 & 21.72 & 1.27 & 0.18 & 17 & 22.37 & 1.89 & -0.47 & $\begin{array}{l}\mathrm{R} 44 \\
\mathrm{~L} 44\end{array}$ & $\begin{array}{l}21.3 \\
20.9\end{array}$ & $\left|\begin{array}{l}22.0-20.6 \\
21.6-20.2\end{array}\right|$ & $\begin{array}{l}0.60 \\
1.00\end{array}$ \\
\hline & $\mathrm{C}$ & 10 & 24.50 & 5.11 & 9 & 26.50 & 4.50 & -2.00 & 24 & 27.54 & 7.84 & -3.04 & $\begin{array}{l}\mathrm{R} 28 \\
\mathrm{~L} 27\end{array}$ & $\begin{array}{l}24.1 \\
24.1\end{array}$ & $\begin{array}{l}25.0-23.1 \\
25.4-22.9\end{array} \mid$ & \\
\hline & $P_{1}$ & 20 & 20.85 & 2.34 & 27 & 21.81 & 2.33 & -0.96 & 19 & 21.87 & 6.19 & -1.02 & $\begin{array}{l}\text { R 42 } \\
\text { L 37 }\end{array}$ & $\begin{array}{l}20.1 \\
20.0\end{array}$ & \begin{tabular}{|}
$20.8-19.3$ \\
$20.8-19.2$
\end{tabular} \mid & \\
\hline \multirow[t]{4}{*}{ 顎 } & $\mathrm{P}_{2}$ & 11 & 21.14 & 3.06 & 32 & 21.81 & 2.46 & -0.67 & 19 & 23.31 & 5.68 & $-2 . \widehat{17}$ & $\begin{array}{l}\text { R 33 } \\
\text { L 18 }\end{array}$ & $\begin{array}{l}19.5 \\
20.0\end{array}$ & $\left|\begin{array}{l}20.5-18.4 \\
20.9-19.0\end{array}\right|$ & $\begin{array}{l}1.64 \\
1.14\end{array}$ \\
\hline & $\mathbf{M}_{1}$ & 2 & 17.90 & - & 23 & 18.37 & 2.33 & -0.47 & 24 & 19.45 & 2.57 & -1.55 & $\begin{array}{l}\text { R 43 } \\
\text { L 52 }\end{array}$ & $\begin{array}{l}18.4 \\
18.3\end{array}$ & $\left|\begin{array}{l}19.0-17.7 \\
18.8-17.8\end{array}\right|$ & $\begin{array}{l}-0.50 \\
-0.40\end{array}$ \\
\hline & $\mathbf{M}_{2}$ & 12 & 18.67 & 2.51 & 32 & 17.92 & 1.89 & 0.75 & 15 & 19.13 & 2.97 & -0.46 & $\begin{array}{l}\text { R 39 } \\
\text { L 42 }\end{array}$ & $\begin{array}{l}18.9 \\
17.8\end{array}$ & $\left|\begin{array}{l}19.6-18.2 \\
18.6-17.0\end{array}\right|$ & $\begin{array}{r}-0.37 \\
0.87\end{array}$ \\
\hline & $\mathbf{M}_{3}$ & 14 & 17.71 & 2.18 & 11 & 15.93 & 3.63 & 1.78 & 7 & 18.96 & 1.41 & -1.25 & $\begin{array}{l}\text { R 27 } \\
\text { L 24 }\end{array}$ & $\begin{array}{l}17.3 \\
17.2\end{array}$ & $\left|\begin{array}{|c}18.2-16.4 \\
18.3-16.1\end{array}\right|$ & $\begin{array}{l}0.41 \\
0.51\end{array}$ \\
\hline
\end{tabular}




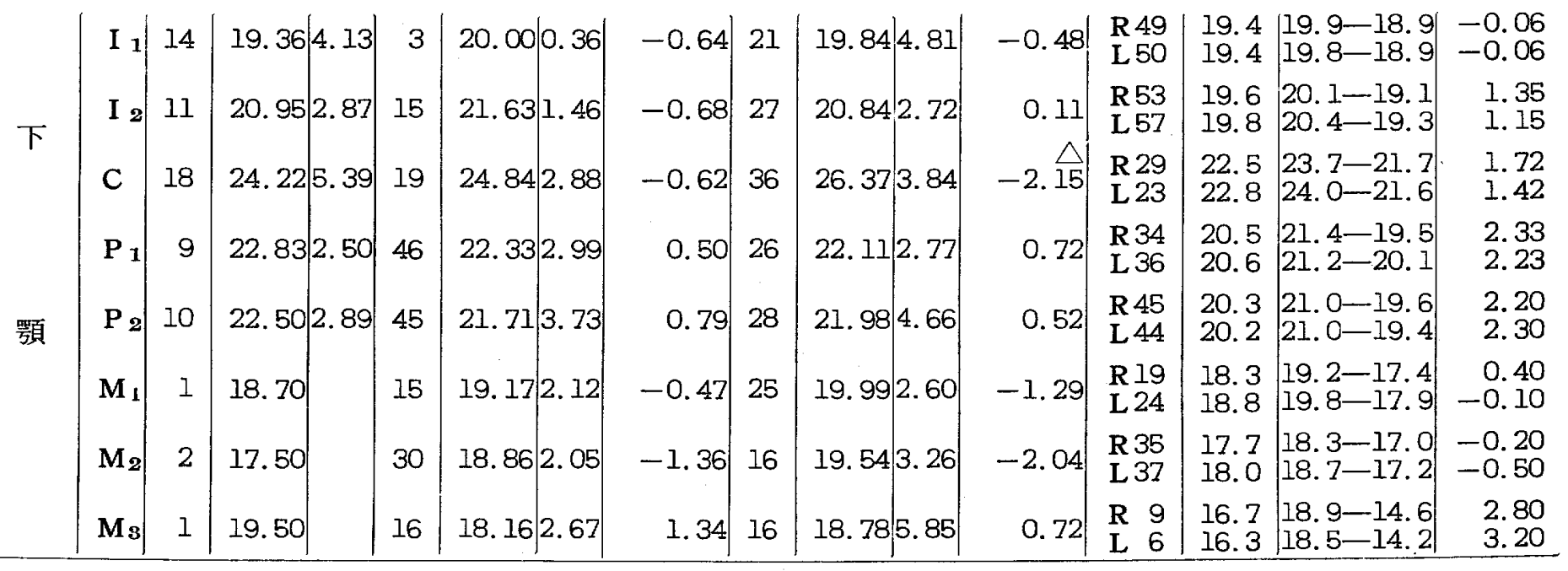

表 8

歯冠 の 幅

\begin{tabular}{|c|c|c|c|c|c|c|c|c|c|c|c|c|c|c|c|c|}
\hline \multirow{2}{*}{$\begin{array}{l}\text { 顎 } \\
\text { 別 }\end{array}$} & \multirow{2}{*}{$\begin{array}{l}\text { 歯 } \\
\text { 別 }\end{array}$} & \multicolumn{3}{|c|}{ 広田遣 跡 } & \multicolumn{3}{|c|}{ 土井ヶ浜遺跡 } & & \multicolumn{3}{|c|}{ 三津 遺 跡 } & & \multicolumn{3}{|c|}{ 現 代 日 本 人 } & \multirow[b]{2}{*}{$\mathbf{M}_{1}-\mathbf{M}_{4}$} \\
\hline & & $\mathbf{N}$ & $M_{1}$ & $\mathrm{U}^{2}$ & $\mathbf{N}$ & $\mathbf{M}_{2}$ & $\mathrm{U}^{2} \mid 1$ & $\mathbf{M}_{1}-\mathbf{M}_{2}$ & $\mathbf{N}$ & $\mathbf{M}_{3}$ & $\mathrm{U}^{2}$ & $\mathbf{M}_{1}-\mathbf{M}_{\mathbf{3}}$ & $\mathbf{N}$ & $\mathbf{M}_{4}$ & C. I & \\
\hline \multirow{4}{*}{ 上 } & $I_{1}$ & 122 & 8.05 & $0.50 \mid$ & 15 & 8. 37 & 0.24 & -0.32 & 20 & 8.42 & .18 & $-0 . \widehat{37}$ & $\begin{array}{l}\text { R 43 } \\
\text { L 39 }\end{array}$ & $\begin{array}{l}8.5 \\
8.4\end{array}$ & $\begin{array}{l}8.7-8.4 \\
8.6-8.2\end{array}$ & $\begin{array}{l}-0.45 \\
-0.35\end{array}$ \\
\hline & $\mathrm{I}_{2}$ & 62 & 6.61 & $0.67 \mid$ & 16 & & 0.31 & -0.31 & 15 & 7.24 & 0.30 & $-0 . \widehat{.63}$ & $\begin{array}{l}\mathrm{R} 44 \\
\mathrm{~L} 44\end{array}$ & $\begin{array}{l}6.9 \\
6.8\end{array}$ & $\begin{array}{l}7.1-6.6 \\
7.0-6.5\end{array}$ & $\begin{array}{l}-0.29 \\
-0.19\end{array}$ \\
\hline & $\mathrm{C}$ & 86 & 7.06 & 0.43 & 9 & 7.8 & 0.25 & -0 . & 24 & 7.86 & 0.33 & $-0 . \widehat{80}$ & $\begin{array}{l}\text { R } 28 \\
\text { L } 27\end{array}$ & $\begin{array}{l}7.5 \\
7.6\end{array}$ & $\begin{array}{l}7.7-7.2 \\
8.0-7.3\end{array}$ & $\begin{array}{l}-0.44 \\
-0.54\end{array}$ \\
\hline & $P_{1}$ & 125 & 6.96 & $0.22 \mid$ & 30 & 7.4 & 0.15 & -0.90 & 17 & 7.03 & 0.36 & -0.07 & $\begin{array}{l}\text { R } 42 \\
\text { L 37 }\end{array}$ & $\begin{array}{l}7.2 \\
7.2\end{array}$ & $\begin{array}{l}7.4-7.1 \\
7.4-7.0\end{array}$ & $\begin{array}{l}-0.24 \\
-0.24\end{array}$ \\
\hline \multirow[t]{4}{*}{ 顎 } & $\mathbf{P}_{2}$ & 111 & 6.42 & 0.28 & 34 & 6.5 & 0.13 & $-0 . \widehat{57}$ & 19 & 6.70 & 0.27 & $-0 . \widehat{28}$ & $\begin{array}{l}\text { R } 33 \\
\text { L } 18\end{array}$ & $\begin{array}{l}6.8 \\
6.7\end{array}$ & $\begin{array}{r}7.1-6.5 \\
7.1-6.4\end{array}$ & $\begin{array}{l}-0.38 \\
-0.28\end{array}$ \\
\hline & $M_{1}$ & 118 & 9.81 & 0.63 & 40 & & 0.23 & -0. & 22 & 10.37 & 0.28 & $-0 . \widehat{56}$ & $\begin{array}{l}\text { R } 43 \\
\mathrm{~L} 12\end{array}$ & $\begin{array}{l}10.5 \\
10.5\end{array}$ & $\begin{array}{l}10.7-10.2 \\
10.7-10.3\end{array}$ & $\begin{array}{l}-0.69 \\
-0.69\end{array}$ \\
\hline & $\mathbf{M}_{2}$ & 119 & $9.2 \varepsilon$ & 0.61 & 36 & 9.77 & 0.47 & -0.49 & 16 & 9.68 & 0.23 & -0.40 & $\begin{array}{l}\text { R } 39 \\
\text { L 42 }\end{array}$ & $\begin{array}{l}9.6 \\
9.7\end{array}$ & $\begin{array}{r}9.8-9.4 \\
10.0-9.4\end{array}$ & $\begin{array}{l}-0.32 \\
-0.42\end{array}$ \\
\hline & $\mathrm{M}_{\mathbf{3}}$ & 82 & 8.21 & 0.74 & 12 & 8.99 & 1.02 & -0.78 & 7 & 8.05 & 1.26 & 0.16 & $\begin{array}{l}\text { R } 27 \\
\text { L } 24 \\
\end{array}$ & $\begin{array}{l}8.9 \\
9.1 \\
\end{array}$ & $\begin{array}{r}9.3-8.6 \\
9.6-8.5 \\
\end{array}$ & $\begin{array}{r}-0.69 \\
-0.89 \\
\end{array}$ \\
\hline \multirow{4}{*}{ 下 } & $I_{1}$ & 115 & 5.22 & 0.33 & 8 & 5.80 & 0.05 & & 14 & 5.40 & 0.19 & -0.18 & $\begin{array}{l}\mathrm{R} 49 \\
\mathrm{~L} 50\end{array}$ & $\begin{array}{l}5.3 \\
5.3\end{array}$ & $\begin{array}{l}5.5-5.2 \\
5.4-5.1\end{array}$ & $\begin{array}{l}-0.08 \\
-0.08\end{array}$ \\
\hline & $\mathrm{I}_{2}$ & 113 & 5.58 & 0.34 & 20 & 6.08 & 0.11 & -0.5 & 27 & 5.99 & 0.23 & & $\begin{array}{l}\text { R } 53 \\
\text { L 57 }\end{array}$ & $\begin{array}{l}5.9 \\
5.9\end{array}$ & $\begin{array}{l}6.0-5.7 \\
6.0-5.7\end{array}$ & $\begin{array}{l}-0.32 \\
-0.32\end{array}$ \\
\hline & C & 147 & 6.43 & 0.25 & 24 & 6.76 & 0.08 & -0.3 & 36 & 6.96 & 0.23 & $-0 . \widehat{53}$ & $\begin{array}{l}\text { R 29 } \\
\text { L 23 }\end{array}$ & $\begin{array}{l}6.7 \\
6.7\end{array}$ & $\begin{array}{l}7.0-6.3 \\
7.0-6.4\end{array}$ & $\begin{array}{l}-0.27 \\
-0.27\end{array}$ \\
\hline & $P_{1}$ & 143 & 6.72 & 0.23 & 51 & 7.18 & 0.17 & -0.46 & 25 & 7.05 & 0.27 & $-0 . \widehat{33}$ & $\begin{array}{l}\text { R 34 } \\
\text { L 36 }\end{array}$ & $\begin{array}{l}7.1 \\
7.0\end{array}$ & $\begin{array}{l}7.3-6.8 \\
7.2-6.8\end{array}$ & $\begin{array}{l}-0.38 \\
-0.28\end{array}$ \\
\hline \multirow[t]{4}{*}{ 䫟 } & $\mathbf{P}_{\mathbf{2}}$ & 145 & 6.88 & 0.26 & 49 & 7.37 & 0.18 & & 28 & 7.23 & 0.23 & $-0 . \widehat{35}$ & $\begin{array}{l}\mathrm{R} 45 \\
\mathrm{~L} 44\end{array}$ & $\begin{array}{l}7.2 \\
7.1\end{array}$ & $\begin{array}{l}7.4-7.0 \\
7.3-7.0\end{array}$ & $\begin{array}{l}-0.32 \\
-0.21\end{array}$ \\
\hline & $\mathbf{M}_{\mathbf{1}}$ & 140 & 11.01 & 0.45 & 26 & 11.58 & 0.21 & $-0 . \widehat{57}$ & 26 & 11.14 & 0.30 & -0.13 & $\begin{array}{l}\text { R } 19 \\
\text { L } 24\end{array}$ & $\begin{array}{l}11.6 \\
11.4\end{array}$ & $\left|\begin{array}{l|}12.0-11.2 \\
11.8-11.0\end{array}\right|$ & $\begin{array}{l}-0.59 \\
-0.39\end{array}$ \\
\hline & $\mathbf{M}_{\mathbf{2}}$ & 144 & 10.60 & 0.44 & 34 & 11.03 & 0.64 & & 16 & 10.70 & 0.65 & -0.10 & $\begin{array}{l}\text { R } 35 \\
\text { L 37 }\end{array}$ & $\begin{array}{l}11.0 \\
11.0\end{array}$ & $\begin{array}{l}11.3-10.6 \\
11.3-10.7\end{array}$ & $\begin{array}{l}-0.40 \\
-0.40\end{array}$ \\
\hline & $\mathrm{M}_{3}$ & 79 & 9.97 & 0.56 & 20 & 10.80 & 0.49 & $-0 . \widehat{83}$ & 16 & 10.27 & 0.60 & -0.30 & $\begin{array}{ll}R & 9 \\
\text { L } & 6\end{array}$ & $\begin{array}{r}9.6 \\
10.2\end{array}$ & $\begin{array}{l}11.1-8.2 \\
13.4-7.1\end{array}$ & $\begin{array}{r}0.37 \\
-0.23 \\
\end{array}$ \\
\hline
\end{tabular}




\begin{tabular}{|c|c|c|c|c|c|c|c|c|c|c|c|c|c|c|c|c|}
\hline & & & & & & & 冠 & の & & 芼 & & & & & & \\
\hline \multirow{2}{*}{$\begin{array}{l}\text { 澦 } \\
\text { 別 }\end{array}$} & \multirow{2}{*}{$\begin{array}{l}\text { 䨛 } \\
\text { 別 }\end{array}$} & \multicolumn{3}{|c|}{ 広田遺跡 } & \multicolumn{3}{|c|}{ 土开ヶ浜遺跡 } & & \multicolumn{3}{|c|}{ 三津 遺 跡 } & & \multicolumn{3}{|c|}{ 現代 日 本人 } & \multirow[b]{2}{*}{$\mathbf{M}_{1}-\mathbf{M}_{4}$} \\
\hline & & $\mathbf{N}$ & $\mathbf{M}_{1}$ & $\mathrm{U}^{2}$ & $\mathbf{N}$ & $\mathbf{M}_{2}$ & $\mathrm{U}^{2} \mathrm{I}$ & $\mathbf{M}_{1}-\mathbf{M}_{2}$ & $\mathbf{N}$ & M3 & $\mathrm{U}^{2}$ & $\left|\mathbf{M}_{1}-\mathbf{M}_{3}\right|$ & $\mathbf{N}$ & $\mathbf{M}_{4}$ & C. I & \\
\hline \multirow{4}{*}{ 上 } & I 1 & 120 & 7.44 & 0.25 & 13 & 7.29 & 0.11 & 0.15 & 20 & 7.30 & 0.07 & 0.14 & $\begin{array}{l}\text { R 43 } \\
\text { L 39 }\end{array}$ & $\begin{array}{l}7.2 \\
7.1\end{array}$ & $\begin{array}{l}7.4-7.1 \\
7.3-6.9\end{array}$ & $\begin{array}{l}0.24 \\
0.34\end{array}$ \\
\hline & $I_{2}$ & 62 & 6.67 & 0.47 & 14 & 6.69 & 0.26 & -0.02 & 16 & 6.75 & 0.41 & -0.08 & $\begin{array}{l}\mathrm{R} 44 \\
\mathrm{~L} 44\end{array}$ & $\begin{array}{l}6.4 \\
6.4\end{array}$ & $\begin{array}{l}6.7-6.2 \\
6.6-6.2\end{array}$ & $\begin{array}{l}0.27 \\
0.27\end{array}$ \\
\hline & C & 84 & 7.91 & 0.34 & 9 & 8.03 & 0.06 & -0.12 & 24 & 8.46 & 0.18 & $-0 . \widehat{55}$ & $\begin{array}{l}\text { R } 28 \\
\text { L } 27\end{array}$ & $\begin{array}{l}8.1 \\
7.9\end{array}$ & $\begin{array}{l}8.3-7.9 \\
8.3-7.6\end{array}$ & $\begin{array}{r}-0.19 \\
0.01\end{array}$ \\
\hline & $\mathbf{P}_{1}$ & 125 & 9.32 & 0.37 & 30 & 9.49 & 0.63 & -0.17 & 18 & 9.23 & 0.19 & 0.09 & $\begin{array}{l}\text { R 42 } \\
\text { L 37 }\end{array}$ & $\begin{array}{l}9.6 \\
9.5\end{array}$ & $\begin{array}{l}9.8-9.4 \\
9.7-9.3\end{array}$ & $\begin{array}{l}-0.28 \\
-0.18\end{array}$ \\
\hline \multirow[t]{4}{*}{ 顎 } & $\mathbf{P}_{\mathbf{2}}$ & 111 & 9.06 & 0.35 & 35 & 9.35 & 0.35 & $-0 . \widehat{29}$ & 19 & 9.05 & 0.30 & 0.01 & $\begin{array}{l}\text { R } 33 \\
\text { L } 18\end{array}$ & $\begin{array}{l}9.2 \\
9.0\end{array}$ & $\begin{array}{l}9.4-8.9 \\
9.4-8.7\end{array}$ & $\begin{array}{r}-0.14 \\
0.166\end{array}$ \\
\hline & $\mathbf{M}_{\mathbf{1}}$ & 118 & 11.62 & 0.44 & 40 & 11.65 & 0.48 & -0.03 & 23 & 11.49 & 0.17 & 0.13 & $\begin{array}{l}\text { R 43 } \\
\text { L 52 }\end{array}$ & $\begin{array}{l}11.8 \\
12.1\end{array}$ & $\begin{array}{l}12.1-11.2 \\
12.3-11.9\end{array}$ & $\begin{array}{l}-0.18 \\
-0.43\end{array}$ \\
\hline & $\mathbf{M}_{\mathbf{2}}$ & 118 & 11.36 & 0.51 & 39 & 11.32 & 0.28 & 0.04 & 16 & 11.28 & 0.37 & 0.08 & $\begin{array}{l}\text { R } 39 \\
\text { L } 42\end{array}$ & $\begin{array}{l}11.5 \\
11.3\end{array}$ & $\begin{array}{l}11.7-11.2 \\
11.7-11.0\end{array}$ & $\begin{array}{r}-0.14 \\
0.06\end{array}$ \\
\hline & $\mathbf{M} 3$ & 82 & 10.75 & 0.85 & 12 & 11.03 & 0.32 & -0.28 & 7 & 10.50 & 2.77 & 0.25 & $\begin{array}{l}\mathrm{R} 27 \\
\mathrm{~L} 24 \\
\end{array}$ & $\begin{array}{l}10.7 \\
10.6\end{array}$ & $\begin{array}{r}11.3-10.2 \\
11.3-9.9\end{array}$ & $\begin{array}{l}0.05 \\
0.15 \\
\end{array}$ \\
\hline \multirow{4}{*}{ 下 } & $I_{1}$ & 113 & 6.01 & 0.31 & 8 & 6.14 & 0.08 & -0.13 & 18 & 5.98 & 0.07 & 0.03 & $\begin{array}{l}\text { R } 49 \\
\text { L 50 }\end{array}$ & $\begin{array}{l}5.9 \\
5.8\end{array}$ & $\mid \begin{array}{l}6.0-5.8 \\
6.0-5.6\end{array}$ & $\begin{array}{l}0.11 \\
0.21\end{array}$ \\
\hline & $I_{2}$ & 113 & 6.36 & $0.22 \mid$ & 20 & 6.24 & 0.08 & 0.12 & 29 & 6.29 & 0.17 & 0.07 & $\begin{array}{l}\text { R } 53 \\
\text { L 57 }\end{array}$ & $\begin{array}{l}6.2 \\
6.1\end{array}$ & $\begin{array}{l}6.4-6.1 \\
6.2-6.0\end{array}$ & $\begin{array}{l}0.16 \\
0.26\end{array}$ \\
\hline & C & 147 & 7.49 & 0.40 & 24 & 7.59 & 0.25 & -0.10 & 37 & 7.90 & 0.29 & $-0 . \widehat{59}$ & $\begin{array}{l}\text { R } 29 \\
\text { L } 23\end{array}$ & $\begin{array}{l}7.4 \\
7.5\end{array}$ & $\begin{array}{l}7.9-7.0 \\
8.0-7.1\end{array}$ & $\begin{array}{r}0.09 \\
-0.01\end{array}$ \\
\hline & $P_{1}$ & 143 & 7. 71 & 0.19 & 52 & 8.00 & 0.21 & -0.29 & 26 & 7.97 & 0.36 & $-0 . \widehat{26}$ & $\begin{array}{l}\text { R } 34 \\
\text { L 36 }\end{array}$ & $\begin{array}{l}7.8 \\
7.9\end{array}$ & $\begin{array}{l}8.1-7.5 \\
8.1-7.6\end{array}$ & $\begin{array}{l}-0.09 \\
-0.19\end{array}$ \\
\hline \multirow[t]{4}{*}{ 顎 } & $\mathbf{P}_{2}$ & 145 & 8.33 & 0.33 & 52 & 8.39 & 0.21 & -0.06 & 28 & 8.25 & 0.29 & 0.08 & $\begin{array}{l}\mathrm{R} 45 \\
\mathrm{~L} 44\end{array}$ & $\begin{array}{l}8.5 \\
8.3\end{array}$ & $\begin{array}{l}8.7-8.3 \\
8.5-8.1\end{array}$ & \begin{tabular}{r|r}
-0.17 \\
0.03
\end{tabular} \\
\hline & $\mathbf{M}_{1}$ & 140 & 10.88 & 0.22 & 26 & 10.99 & 0.19 & -0.11 & 26 & 10.82 & $0.40 \mid$ & 0.06 & $\begin{array}{l}\mathrm{R} 19 \\
\mathrm{~L} 24\end{array}$ & $\begin{array}{l}10.3 \\
10.7\end{array}$ & $\begin{array}{l}11.1-10.6 \\
11.0-10.4\end{array}$ & $\begin{array}{l}0.08 \\
0.18\end{array}$ \\
\hline & $\mathbf{M}_{2}$ & 144 & 10.41 & 0.38 & 36 & 10.39 & 0.35 & 0.02 & 16 & 10.17 & 0.28 & 0.24 & $\begin{array}{l}\text { R 35 } \\
\text { L 37 }\end{array}$ & $\begin{array}{l}10.2 \\
10.2\end{array}$ & $\begin{array}{l}10.5-9.9 \\
10.4-10.0\end{array}$ & $\begin{array}{l}0.21 \\
0.21\end{array}$ \\
\hline & $\mathbf{M} 3$ & 79 & 9.95 & 0.37 & 20 & 10.23 & 0.53 & -0.28 & 16 & 9.88 & 0.52 & 0.07 & $\begin{array}{ll}\mathrm{R} & 9 \\
\mathrm{~L} & 6 \\
\end{array}$ & $\begin{array}{l}9.3 \\
9.7 \\
\end{array}$ & $\begin{array}{l}10.2-8.3 \\
11.5-7.9\end{array}$ & $\begin{array}{l}0.65 \\
0.25\end{array}$ \\
\hline
\end{tabular}

\begin{tabular}{|c|c|c|c|c|c|c|c|c|c|c|c|c|c|c|}
\hline \multirow[b]{2}{*}{ 歯 } & \multirow[b]{2}{*}{ 別 } & \multicolumn{3}{|c|}{ 広 田 遗 跡 } & \multicolumn{4}{|c|}{ 土井ケ浜 遗 跡 } & \multicolumn{3}{|c|}{ 三 津 遺 跡 } & \multicolumn{3}{|c|}{ 現代日本人 } \\
\hline & & $\mathbf{N}$ & $\mathbf{M}_{1}$ & $\mathrm{U}^{2}$ & $\mathbf{N}$ & $\mathbf{M}_{2}$ & $\mathrm{U}^{2}$ & $\left|\mathbf{M}_{1}-\mathbf{M}_{2}\right|$ & $\mathbf{N}$ & $\mathbf{M}_{\mathbf{3}}$ & $\mathbf{M}_{1}-\mathbf{M}_{3}$ & $\mathbf{N}$ & $\mathbf{M}_{4}$ & $\mathbf{M}_{1}-\mathbf{M}_{4}$ \\
\hline \multirow{4}{*}{ 上: } & $I_{1}$ & 121 & 107.6 & 70.79 & 13 & 115.8 & 58.70 & $\begin{array}{r}0 \\
-8.2\end{array}$ & 20 & 115.27 & -7.67 & $\begin{array}{l}\text { R39 } \\
\text { L 43 }\end{array}$ & $\begin{array}{l}118.9 \\
118.5\end{array}$ & $\begin{array}{l}-11.3 \\
-10.9\end{array}$ \\
\hline & $I_{2}$ & 61 & 99.6 & 142.88 & 14 & 103.3 & 19. 14 & -3 & 15 & 107.58 & -7.98 & $\begin{array}{l}\mathrm{R} 44 \\
\mathrm{~L} 44\end{array}$ & $\begin{array}{l}105.9 \\
107.2\end{array}$ & $\begin{array}{l}-6.3 \\
-7.6\end{array}$ \\
\hline & $\mathrm{C}$ & 84 & 89.3 & 72.88 & 9 & $\subseteq 6 . \varsigma$ & 52.86 & -7 & 24 & 92.99 & -3.69 & $\begin{array}{l}\text { R } 27 \\
\text { L 28 }\end{array}$ & $\begin{array}{l}95.9 \\
92.4\end{array}$ & $\begin{array}{l}-6.6 \\
-3.1\end{array}$ \\
\hline & $\mathbf{P}_{1}$ & 123 & 74.9 & 28.64 & 29 & 78.9 & 8.79 & & 17 & 76.17 & -1.27 & $\begin{array}{l}\text { R } 37 \\
\text { L 42 }\end{array}$ & $\begin{array}{l}75.5 \\
75.2\end{array}$ & $\begin{array}{l}-0.6 \\
-0.3\end{array}$ \\
\hline \multirow[t]{4}{*}{ 顎 } & $\mathbf{P}^{2}$ & 109 & 71.6 & 29.93 & 34 & 74.8 & 27.22 & & 19 & 74.61 & -3.01 & $\begin{array}{l}\text { R } 18 \\
\text { L 33 }\end{array}$ & $\begin{array}{l}74.3 \\
74.4\end{array}$ & $\begin{array}{l}-2.7 \\
-2.8\end{array}$ \\
\hline & $\mathbf{M}_{1}$ & 115 & 84.7 & 31.00 & 40 & 92.3 & 30.40 & -7.6 & 22 & 90.56 & -5.86 & $\begin{array}{l}\text { R } 52 \\
\text { L } 43\end{array}$ & $\begin{array}{l}86.8 \\
89.0\end{array}$ & $\begin{array}{l}-2.1 \\
-4.3\end{array}$ \\
\hline & $\mathbf{M}_{2}$ & 119 & 81.4 & 34.30 & $\Xi 6$ & 86.4 & 20.43 & -5 & 16 & 85.88 & -4.48 & $\begin{array}{l}\text { R } 42 \\
\text { L 39 }\end{array}$ & $\begin{array}{l}85.7 \\
83.9\end{array}$ & $\begin{array}{l}-4.3 \\
-2.5\end{array}$ \\
\hline & $\mathbf{M}_{3}$ & 80 & 76.6 & 45.76 & 12 & 81.5 & 36.82 & -4.9 & 7 & 77.27 & -0.67 & $\begin{array}{l}\mathrm{R} 24 \\
\mathrm{~L} 27 \\
\end{array}$ & $\begin{array}{l}86.3 \\
83.7 \\
\end{array}$ & $\begin{array}{r}-9.7 \\
-7.1 \\
\end{array}$ \\
\hline
\end{tabular}




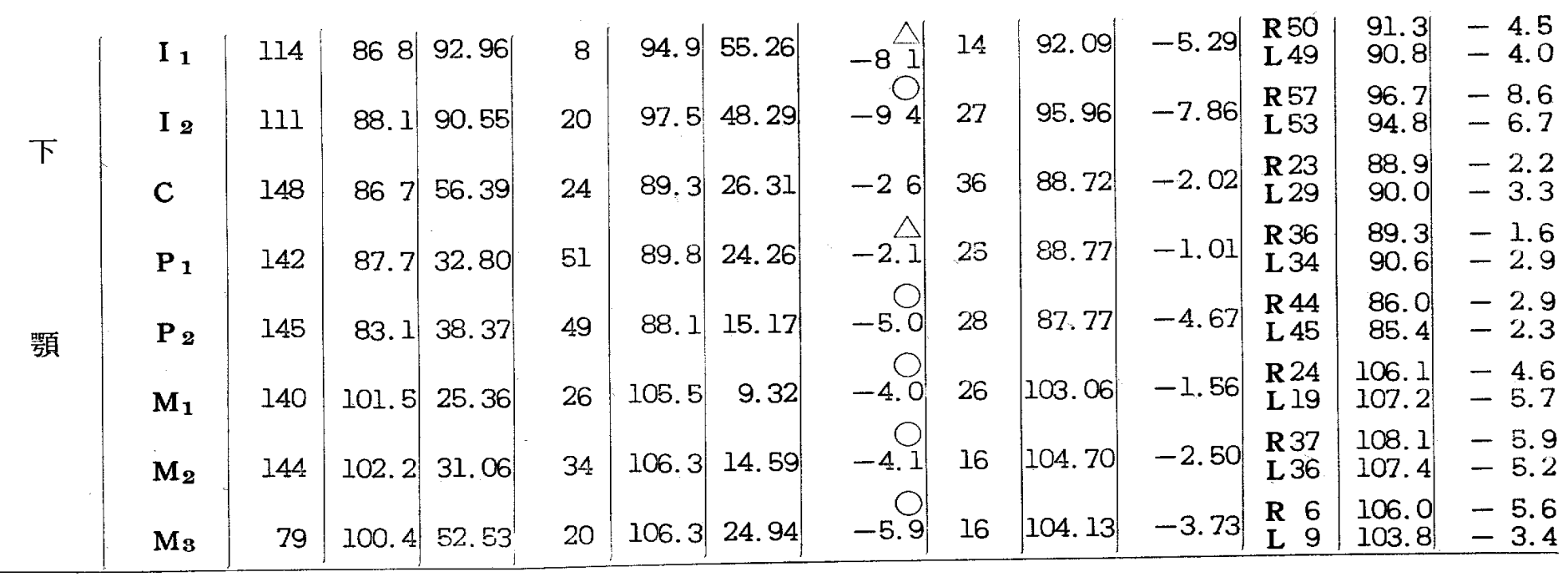

\begin{tabular}{|c|c|c|c|c|c|c|c|c|c|c|c|c|c|c|}
\hline \multirow[b]{2}{*}{ 歯 } & \multirow[b]{2}{*}{ 別 } & \multicolumn{3}{|c|}{ 広 田 遗 跡 } & \multicolumn{4}{|c|}{ 土井 ケ 浜 遺 跡 } & \multicolumn{3}{|c|}{ 三 津 遺 跡 } & \multicolumn{3}{|c|}{ 現代日本人 } \\
\hline & & $\mathbf{N}$ & $\mathbf{M}_{1}$ & $\mathrm{U}^{2}$ & $\mathbf{N}$ & $\mathbf{M}_{2}$ & $\mathrm{U}^{2}$ & $\left|\mathbf{M}_{1}-\mathbf{M}_{2}\right|$ & $\mathbf{N}$ & Ma $I$ & $\mathbf{M}_{1}-\mathbf{M}_{3}$ & $\mathbf{N}$ & $\mathbf{M}_{4}$ & $\mathbf{M}_{1}-\mathbf{M}_{4}$ \\
\hline \multirow{4}{*}{ 上 } & $\mathrm{I}_{1}$ & 19 & 80.611 & 170.36 & 15 & 85.5 & 47.40 & $-4.9 \mid$ & 5 & 78.6 & 2.0 & $\begin{array}{l}\text { R 43 } \\
\text { L 39 }\end{array}$ & $\begin{array}{r}100.7 \\
98.1\end{array}$ & $\begin{array}{l}-20.1 \\
-17.4\end{array}$ \\
\hline & $\mathrm{I}_{2}$ & 5 & 72.0 & 42.50 & 16 & 69.91 & 103.53 & 2.1 & 4 & 71.6 & 0.4 & $\begin{array}{l}\text { R } 44 \\
\text { L 44 }\end{array}$ & $\begin{array}{l}86.2 \\
87.8\end{array}$ & $\begin{array}{l}-14.2 \\
-15.8\end{array}$ \\
\hline & $\mathrm{C}$ & 10 & 68.01 & 127.77 & 9 & 61.9 & 25.36 & 6.1 & 6 & 65.3 & 2.7 & $\begin{array}{l}\text { R } 28 \\
\text { L 27 }\end{array}$ & $\begin{array}{l}69.5 \\
74.1\end{array}$ & $\begin{array}{l}-1.5 \\
-6.9\end{array}$ \\
\hline & $\mathbf{P}_{1}$ & 20 & 56.2 & 42.82 & 27 & 58.5 & 63.57 & -2.3 & 8 & 52.7 & 3.5 & $\begin{array}{l}\text { R } 42 \\
\text { L 37 }\end{array}$ & $\begin{array}{l}65.7 \\
63.1\end{array}$ & $\begin{array}{l}-9.5 \\
-6.9\end{array}$ \\
\hline \multirow[t]{4}{*}{ 顎 } & $\mathbf{P}_{2}$ & 11 & 52.1 & 59.10 & 32 & 48.9 & 44.03 & 3.2 & 8 & 48.8 & 3.3 & $\begin{array}{l}\text { R 33 } \\
\text { L 18 }\end{array}$ & $\begin{array}{l}65.4 \\
59.8\end{array}$ & $\begin{array}{r}-13.3 \\
-7.7\end{array}$ \\
\hline & $M_{1}$ & 3 & 62.6 & - & 23 & 57.0 & 31.09 & 5.6 & 11 & 54.9 & 7.7 & $\begin{array}{l}\text { R 43 } \\
\text { L 52 }\end{array}$ & $\begin{array}{l}61.4 \\
60.4\end{array}$ & $\begin{array}{l}1.2 \\
2.2\end{array}$ \\
\hline & $\mathbf{M}_{2}$ & 12 & 57.1 & 49.21 & 32 & 57.5 & 61.81 & -0.4 & 5 & 56.3 & 0.8 & $\begin{array}{l}\text { R } 39 \\
\text { L 42 }\end{array}$ & $\begin{array}{l}57.8 \\
62.0\end{array}$ & $\begin{array}{l}-0.7 \\
-\quad 4.9\end{array}$ \\
\hline & $\mathbf{M}_{3}$ & 14 & 59.0 & 93.27 & 11 & 57.8 & 93.78 & 1.2 & 3 & 59.5 & -0.5 & $\begin{array}{l}\text { R } 27 \\
\text { L 24 } \\
\end{array}$ & $\begin{array}{l}59.8 \\
60.9 \\
\end{array}$ & $\begin{array}{r}-0.8 \\
-\quad 1.9 \\
\end{array}$ \\
\hline \multirow{4}{*}{ 下 } & $I_{1}$ & 14 & $70.1 \mid$ & 102.71 & 3 & 73.0 & 23.25 & -2.9 & 3 & 75.1 & -5.0 & $\begin{array}{l}\mathbf{R} 49 \\
\text { L } 50\end{array}$ & $\begin{array}{l}78.9 \\
78.0\end{array}$ & $\begin{array}{l}-8.8 \\
-7.9\end{array}$ \\
\hline & $I_{2}$ & 12 & 69.6 & 69.75 & 15 & 64.5 & 76.27 & 5.1 & 6 & 70.0 & -0.4 & $\begin{array}{l}\text { R53 } \\
\text { L } 57\end{array}$ & $\begin{array}{l}82.4 \\
76.0\end{array}$ & $\begin{array}{l}-12.8 \\
-6.4\end{array}$ \\
\hline & $\mathrm{C}$ & 17 & 70.6 & 65.97 & 19 & $67.4]$ & 110.76 & 6.8 & 10 & 73. 4 & -2.8 & $\begin{array}{l}\mathrm{R} 29 \\
\mathrm{~L} 23\end{array}$ & $\begin{array}{l}75.5 \\
72.1\end{array}$ & $\begin{array}{l}-4.9 \\
-1.5\end{array}$ \\
\hline & $P_{1}$ & 10 & 56.3 & 21.97 & 46 & 55.4 & 74.80 & 0.9 & 8 & 58.7 & -2.4 & $\begin{array}{l}\text { R 34 } \\
\text { L 36 }\end{array}$ & $\begin{array}{l}63.7 \\
60.4\end{array}$ & $\begin{array}{l}-7.4 \\
-4.1\end{array}$ \\
\hline \multirow[t]{4}{*}{ 顎 } & $\mathrm{P}_{2}$ & 10 & 51.0 & 40.00 & 45 & 47.6 & 36.42 & 3.4 & 7 & 51.8 & -0.8 & $\begin{array}{l}\text { R } 45 \\
\text { L 44 }\end{array}$ & $\begin{array}{l}58.0 \\
55.1\end{array}$ & $\begin{array}{l}-7.0 \\
-4.1\end{array}$ \\
\hline & $\mathbf{M}_{1}$ & 0 & - & - & 15 & 50.3 & 29.35 & - & 6 & 55.5 & - & $\begin{array}{l}\text { R } 19 \\
\text { L } 24\end{array}$ & $\begin{array}{l}63.0 \\
55.5\end{array}$ & - \\
\hline & $\mathbf{M}_{2}$ & 2 & 67.5 & - & 30 & 48.8 & 40.10 & 18.7 & 3 & 53.7 & 13.8 & $\begin{array}{l}\text { R 35 } \\
\text { L 37 }\end{array}$ & $\begin{array}{l}44.9 \\
58.8\end{array}$ & $\begin{array}{r}22.6 \\
8.7\end{array}$ \\
\hline & $\mathrm{M} 3$ & 1 & 64.0 & - & 16 & 49.4 & 56.64 & 4.6 & 7 & 62.8 & 1.2 & $\begin{array}{ll}R & 9 \\
\mathrm{~L} & 6 \\
\end{array}$ & $\begin{array}{l}59.3 \\
61.7\end{array}$ & $\begin{array}{l}4.7 \\
2.3 \\
\end{array}$ \\
\hline
\end{tabular}


く . 三津弥生式人に比べると上下顎犬霜ならびに下顎第 l小臼歯は有意差を示して小さいが，その他の歯ではほ とんよ゙差異はない，現代日本人に比べると大きな差異は 認められない。

歯冠幅愿指数

これは荬冠の幅を厚さで除したものを100倍した数值 である．表10に示すごとく土井ケ浜怙よび三津弥生式人 に比べ有意差を示して小さい．また現代日本人に比べて 屯差が認められる。このことは広田弥生式人の菌は歯冠 の類舌径に対して近遠心径が比較的に小さいととを示し ている.

\section{冠根指数}

これは菊冠の長さを崡根の長さで除したすのを 100 倍 した数值で, 表lにに示すごとく土井ケ浜および三津弥生 式人とは大きな差は認められず，現代日本人に比べると 指数值は小さくなっており，歯根が歯冠に対して比較的

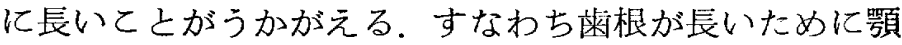
骨に対して骨植堅固であったものと考えられる。

3. 霜牙形態の観察成績

( 1 ) 前歯部

シャベル型切歯

上枵中切曾では TR が $42 \%$ で眼も多く次いで $\mathrm{SS}$,

上顎切霖 の Shovel-Shape Incisor

\begin{tabular}{|c|c|c|c|c|c|c|c|}
\hline & & & 1 (s) & 2 (ss) & $3(\operatorname{tr})$ & 4 (no) & Total \\
\hline \multirow{3}{*}{$\mathrm{I}_{1}$} & $\mathbf{R}$ & $\begin{array}{l}\mathrm{N} \\
\%\end{array}$ & & $\begin{array}{c}13 \\
25.00 \pm 6.00\end{array}$ & $\begin{array}{c}24 \\
46.15 \pm 6.91\end{array}$ & $\begin{array}{c}15 \\
28.85 \pm 6.28\end{array}$ & 52 \\
\hline & L & $\begin{array}{l}\mathrm{N} \\
\%\end{array}$ & $\begin{array}{c}3 \\
5.00 \pm 2.81\end{array}$ & $\begin{array}{c}20 \\
33.33 \pm 6.08\end{array}$ & $\begin{array}{c}23 \\
38.33 \pm 6.27\end{array}$ & $\begin{array}{c}14 \\
23.33 \pm 5.46\end{array}$ & 60 \\
\hline & 計 & $\begin{array}{l}\mathrm{N} \\
\%\end{array}$ & $\begin{array}{c}3 \\
2.68 \pm 1.52\end{array}$ & $\begin{array}{c}33 \\
29.46 \pm 4.37\end{array}$ & $\begin{array}{c}47 \\
41.96 \pm 4.66\end{array}$ & $\begin{array}{c}29 \\
25.89 \pm 4.13\end{array}$ & 112 \\
\hline \multirow{3}{*}{$\mathrm{I}_{2}$} & $\mathbf{R}$ & $\begin{array}{l}\mathrm{N} \\
96\end{array}$ & $\begin{array}{c}6 \\
22.22 \pm 8.00\end{array}$ & $\begin{array}{c}14 \\
51.85 \pm 9.61\end{array}$ & $\begin{array}{c}7 \\
23.93 \pm 8.43\end{array}$ & & 27 \\
\hline & $\mathrm{L}$ & $\begin{array}{l}\mathrm{N} \\
\% 6\end{array}$ & $\begin{array}{c}6 \\
25.00 \pm 8.83\end{array}$ & $\begin{array}{c}13 \\
54.17 \pm 10.17\end{array}$ & $\begin{array}{c}4 \\
16.67 \pm 7.60\end{array}$ & $\begin{array}{c}1 \\
\text { 4. } 17 \pm 4.08\end{array}$ & 24 \\
\hline & 該† & $\begin{array}{l}\mathrm{N} \\
\%\end{array}$ & $\begin{array}{c}12 \\
23.53 \pm 5.93\end{array}$ & $\begin{array}{c}27 \\
52.94 \pm 6.98\end{array}$ & $\begin{array}{c}11 \\
21.57 \pm 5.75\end{array}$ & $\begin{array}{c}1 \\
1.96 \pm 1.94\end{array}$ & 51 \\
\hline
\end{tabular}

NO, S の順となっている, 同じく側切歯では SS か55 \%で最む多く次いで S，TR，NO の順となっている. すなわち側切崡が中切歯よりあ著明に認如る（表 12). 現代日本人と比較すると中切歯ではSの型が非常 に少なく、シャベル型の切蒌は少ないことが認められ る。また中国人やアメリカインディアン人に比べても少 ない，しかしアメリカ白人に比へると多い，（表13，

14)

\section{基底結節の発達状態}

発澾の特に強いあのを+, かなり発達しているあのを 十, 発達の弱いものを土として 分類すると，上顎では $I_{1}$ は+が最も多く次いで+，士の順で比較的上く発達 しているが，I 、は+ははなく+が73.7\% で最も多く，I 1

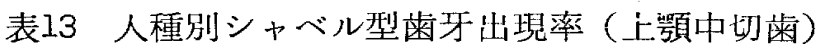

\begin{tabular}{l|r|r|r|r}
\hline \hline & S & SS & TR & NO \\
\hline アメリカ白人 (Hrdlička) & 1.4 & 7.6 & 24.5 & 66.5 \\
アメリカネグロ (Hrdlička) & 4.9 & 7.6 & 33.0 & 54.5 \\
フインランド人 (Koski) & 3.6 & 12.6 & 76.6 & 7.2 \\
インディアン (Dahlberg) & 67.0 & 24.0 & 9.0 & 2.0 \\
中国人 (Hrdlička) & 66.2 & 23.4 & 1.8 & 7.8 \\
中国人 (Stevenson) & 8.3 & 53.9 & 19.7 & 18.2 \\
中国人 (アメリカ在住) (Lasker) & 18.6 & 66.2 & 13.0 & 2.2 \\
日 本 人 (菊 地) & 76.1 & 15.1 & 3.1 & 2.3 \\
日 本 人 (酒 井) & 43.8 & 28.9 & 21.9 & 5.3 \\
弥生式時代人 (山田) & 2.7 & 29.5 & 42.0 & 25.9 \\
\hline
\end{tabular}


表14人種別シャベル型霜牙出現率 (上顎側切歯)

\begin{tabular}{l|l|l|l|l} 
& S & SS & TR & NO \\
\hline \hline アメリカ白人 (Hrdlička) & 1.4 & 8.8 & 36.4 & 50.0 \\
アメリカネグロ (Hrdlička) & 4.5 & 12.8 & 38.0 & 42.1 \\
フインランド人 (Koski) & 3.7 & 20.2 & 68.8 & 7.3 \\
インディアン (Dahlberg) & 76.0 & 17.0 & 6.0 & 1.0 \\
中国人 (Hrdlička) & 56.9 & 24.0 & 1.5 & 9.5 \\
日 本 人 (菊 地) & 74.1 & 16.2 & 2.7 & 1.1 \\
日 本 人 (酒 井) & 38.7 & 25.8 & 29.0 & 6.5 \\
弥生式時代人 (山田) & 23.5 & 52.9 & 21.6 & 2.0 \\
\hline
\end{tabular}

よりやや発達程度が劣っている，Cでは十，H，士の順 序でよく発達している，下顎では $I_{1} ， I_{2} ， C$ を通じて \#はなく+も少なく大部分が士で，上顎に比べた場合発 達程度は少っている，現代日本人と比べた場合大きな差 は認められない，（表15，16）

\section{棘突起}

これは舌側面の基底結節より舌側面禽の方に向ってで ている1〜3コの小咨起状のあのであるが，上顎の I 1 では1〜2コのものが最も多く, 全然ないものは約19\% である。I 2 は大部分が認められない，Cは1コのあの が最む多く57.8\%，次いで全くないあのが35\%である．

上 顎 前 蒾 の 基 底 結 節

\begin{tabular}{|c|c|c|c|c|c|c|}
\hline & & & H & + & \pm & 計 \\
\hline \multirow{3}{*}{$I_{1}$} & $\mathrm{R}$ & $\begin{array}{l}\mathrm{N} \\
\%\end{array}$ & $\begin{array}{c}24 \\
43.64 \pm 6.68\end{array}$ & $\begin{array}{c}30 \\
94.55 \pm 6.71\end{array}$ & $\begin{array}{c}1 \\
1.82 \pm 1.80\end{array}$ & 55 \\
\hline & L & $\begin{array}{l}\mathrm{N} \\
\%\end{array}$ & $\begin{array}{c}27 \\
42.19 \pm \text { E. } 17\end{array}$ & $\begin{array}{c}35 \\
54.69 \pm 6.22\end{array}$ & $\begin{array}{c}2 \\
\text { 3. } 13 \pm 2.17\end{array}$ & 64 \\
\hline & 計 & $\begin{array}{l}\mathbf{N} \\
\%\end{array}$ & $\begin{array}{c}51 \\
42.86 \pm 4.53\end{array}$ & $\begin{array}{c}65 \\
54.62 \pm 4.56\end{array}$ & $\begin{array}{c}3 \\
2.52 \pm 1.43\end{array}$ & 119 \\
\hline \multirow{3}{*}{$I_{2}$} & $\mathbf{R}$ & $\begin{array}{l}\mathrm{N} \\
96\end{array}$ & & $\begin{array}{c}21 \\
70.00 \pm 8.30\end{array}$ & $\begin{array}{c}9 \\
30.00 \pm 8.30\end{array}$ & 30 \\
\hline & $\mathbf{L}$ & $\begin{array}{l}\mathrm{N} \\
\%\end{array}$ & & $\begin{array}{c}21 \\
77.78 \pm 8.00\end{array}$ & $\begin{array}{c}6 \\
22.22 \pm 8.00\end{array}$ & 27 \\
\hline & 計 & $\begin{array}{l}\mathrm{N} \\
\%\end{array}$ & & $\begin{array}{c}42 \\
73 \quad 68 \pm 5.83\end{array}$ & $\begin{array}{c}15 \\
26.32 \pm 5.83\end{array}$ & 57 \\
\hline \multirow{3}{*}{ C } & $\mathbf{R}$ & $\begin{array}{l}\mathrm{N} \\
\%\end{array}$ & $\begin{array}{c}11 \\
27.50 \pm 7.06\end{array}$ & $\begin{array}{c}27 \\
67.50 \pm 7.40\end{array}$ & $\begin{array}{c}2 \\
5.00 \pm 3.44\end{array}$ & 40 \\
\hline & L & $\begin{array}{l}\mathbf{N} \\
96\end{array}$ & $\begin{array}{c}11 \\
28.21 \pm 7.20\end{array}$ & $\begin{array}{c}26 \\
66.67 \pm 7.54\end{array}$ & $\begin{array}{c}2 \\
5.13 \pm 3.53\end{array}$ & 39 \\
\hline & 計 & $\begin{array}{l}\mathrm{N} \\
\%\end{array}$ & $\begin{array}{c}22 \\
27.85 \pm 5.04\end{array}$ & $\begin{array}{c}53 \\
67.09 \pm 5.28\end{array}$ & $\begin{array}{c}4 \\
5.06 \pm 2.46\end{array}$ & 79 \\
\hline
\end{tabular}

現代日本人との比較では大きな差異はないようである。 (表17)

\section{斜切痕}

これは舌側面の辺縁隆線上を斜めに横切っている切痕 であるが, 近心, 遠心いずれにも出現する.その出現頻 度は表18に示すごとくで上顎のI 1 では遠心に3.6\%，近
心に0.9\%，またI 2では遠心に14.6\%，近心に9.1\%上 いずれも遠心に多く，かつI $I_{1}$ よりあ I 2 に多く認めら れる。現代日本人においてもI 上り I 2 亿多いが, 広田 弥生式人は現代日本人に比べると出現頻度は少ない。

盲孔

上顎切歯の舌側面基底結節の前面に潜入した小孔で主 


\begin{tabular}{|c|c|c|c|c|c|c|}
\hline & & & $H$ & + & \pm & 棓 \\
\hline \multirow{3}{*}{$I_{1}$} & $\mathbf{R}$ & $\begin{array}{l}\mathbf{N} \\
\%\end{array}$ & & $\begin{array}{c}1 \\
1.89 \pm 1.87\end{array}$ & $\begin{array}{c}52 \\
98.11 \pm 1.87\end{array}$ & 53 \\
\hline & L & $\begin{array}{l}\mathbf{N} \\
\%\end{array}$ & & & $\begin{array}{c}55 \\
100.00\end{array}$ & 55 \\
\hline & 計 & $\begin{array}{l}\mathbf{N} \\
96\end{array}$ & & $\begin{array}{c}1 \\
0.93 \pm 0.92\end{array}$ & $\begin{array}{c}107 \\
99.07 \pm 0.92\end{array}$ & 108 \\
\hline \multirow{3}{*}{$I_{2}$} & $\mathbf{R}$ & $\begin{array}{l}\mathbf{N} \\
\%\end{array}$ & & $\begin{array}{c}1 \\
1.85 \pm 1.83\end{array}$ & $\begin{array}{c}53 \\
98.15 \pm 1.83\end{array}$ & 54 \\
\hline & L & $\begin{array}{l}\mathrm{N} \\
\%\end{array}$ & & $\begin{array}{c}1 \\
1.85 \pm 1.83\end{array}$ & $\begin{array}{c}53 \\
98.15 \pm 1.83\end{array}$ & 54 \\
\hline & 計 & $\begin{array}{l}\mathbf{N} \\
\%\end{array}$ & & $\begin{array}{c}2 \\
1.85 \pm 1.29\end{array}$ & $\begin{array}{c}106 \\
98.15 \pm 1.29\end{array}$ & 108 \\
\hline \multirow{3}{*}{ C } & $\mathbf{R}$ & $\begin{array}{l}\mathbf{N} \\
\%\end{array}$ & & $\begin{array}{c}10 \\
14.29 \pm 4.18\end{array}$ & $\begin{array}{c}60 \\
85.71 \pm 4.18\end{array}$ & 70 \\
\hline & $\mathbf{L}$ & $\begin{array}{l}\mathrm{N} \\
\%\end{array}$ & & $\begin{array}{c}13 \\
18.57 \pm 4.64\end{array}$ & $\begin{array}{c}57 \\
81.43 \pm 4.64\end{array}$ & 70 \\
\hline & 計 & $\begin{array}{l}\mathbf{N} \\
\%\end{array}$ & & $\begin{array}{c}23 \\
16.43 \pm 3.13\end{array}$ & $\begin{array}{c}117 \\
83.57 \pm 3.13\end{array}$ & 140 \\
\hline
\end{tabular}

上 顎 前 歯 の 棘 突 起

\begin{tabular}{|c|c|c|c|c|c|c|c|}
\hline & & & 0 & 1 & 2 & 3 & Total \\
\hline \multirow{3}{*}{$I_{1}$} & $\mathbf{R}$ & $\%$ & $\begin{array}{c}11 \\
21.57 \pm 5.75\end{array}$ & $\begin{array}{c}15 \\
29.41 \pm 6.38\end{array}$ & $\begin{array}{c}22 \\
\text { 43. } 14 \pm 6.93\end{array}$ & $\begin{array}{c}3 \\
5.88 \pm 3.29\end{array}$ & 51 \\
\hline & L & $\begin{array}{l}\mathbf{N} \\
\%\end{array}$ & $\begin{array}{c}10 \\
17.54 \pm 5.03\end{array}$ & $\begin{array}{c}22 \\
38.60 \pm 6.44\end{array}$ & $\begin{array}{c}22 \\
38.60 \pm 6.44\end{array}$ & $\begin{array}{c}3 \\
5.26 \pm 2.95\end{array}$ & 57 \\
\hline & 計 & $\begin{array}{l}\mathrm{N} \\
96\end{array}$ & $\begin{array}{c}21 \\
19.44 \pm 3.80\end{array}$ & $\begin{array}{c}37 \\
34.26 \pm 4.56\end{array}$ & $\begin{array}{c}44 \\
40.74 \pm 4.72\end{array}$ & $\begin{array}{c}6 \\
5.56 \pm 2.20\end{array}$ & 108 \\
\hline \multirow{3}{*}{$I_{2}$} & $\mathbf{R}$ & $\begin{array}{l}\mathrm{N} \\
96\end{array}$ & $\begin{array}{c}25 \\
96.15 \pm 3.77\end{array}$ & $\begin{array}{c}1 \\
3.85 \pm 3.77\end{array}$ & & & 26 \\
\hline & $\mathbf{L}$ & $\begin{array}{l}\mathbf{N} \\
\%\end{array}$ & $\begin{array}{c}25 \\
92.59 \pm 5.04\end{array}$ & $\begin{array}{c}2 \\
7.41 \pm 5.04\end{array}$ & & & 27 \\
\hline & 計 & $\begin{array}{l}\mathbf{N} \\
96\end{array}$ & $\begin{array}{c}50 \\
94.34 \pm 3.17\end{array}$ & $\begin{array}{c}3 \\
5.66 \pm 3.17\end{array}$ & & & 53 \\
\hline
\end{tabular}




\begin{tabular}{|c|c|c|c|c|c|c|}
\hline \multirow{3}{*}{ C } & $\mathbf{R}$ & $\begin{array}{l}\mathrm{N} \\
8\end{array}$ & $\begin{array}{c}12 \\
33.33 \pm 7.85\end{array}$ & $\begin{array}{c}22 \\
61.11 \pm 8.12\end{array}$ & $\begin{array}{c}2 \\
5.56 \pm 3.81\end{array}$ & 36 \\
\hline & $\mathbf{L}$ & $\begin{array}{l}\mathbf{N} \\
\%\end{array}$ & $\begin{array}{c}13 \\
37.14 \pm 8.16\end{array}$ & $\begin{array}{c}19 \\
54.29 \pm 8.42\end{array}$ & $\begin{array}{c}3 \\
8.57 \pm 4.73\end{array}$ & 35 \\
\hline & 計 & $\%$ & $\begin{array}{c}25 \\
35.21 \pm 5.66\end{array}$ & $\begin{array}{c}41 \\
57.75 \pm 5.86\end{array}$ & $\begin{array}{c}5 \\
7.04 \pm 3.03\end{array}$ & 71 \\
\hline
\end{tabular}
上靧 切歯 $の$ 斜 切痕

\begin{tabular}{|c|c|c|c|c|c|c|}
\hline & & & O & $\mathbf{M}$ & D & 計 \\
\hline \multirow{3}{*}{$\mathrm{I}_{1}$} & $\mathbf{R}$ & $\%$ & $\begin{array}{c}48 \\
94.12 \pm 3.29\end{array}$ & $\begin{array}{c}1 \\
1.96 \pm 1.94\end{array}$ & $\begin{array}{c}2 \\
3.92 \pm 2.71\end{array}$ & 51 \\
\hline & L & $\mathrm{N}$ & $\begin{array}{c}58 \\
96.67 \pm 2.31\end{array}$ & 0 & $\begin{array}{c}2 \\
\text { 3. } 33 \pm 2.31\end{array}$ & 60 \\
\hline & 計 & $\%$ & $\begin{array}{c}106 \\
95.50 \pm 1.96\end{array}$ & $\begin{array}{c}1 \\
0.90 \pm 0.90\end{array}$ & $\begin{array}{c}4 \\
3.60 \pm 1.77\end{array}$ & 111 \\
\hline \multirow{3}{*}{$\mathrm{I}_{2}$} & $\mathbf{R}$ & $\%$ & $\begin{array}{c}19 \\
70.37 \pm 8.78\end{array}$ & $\begin{array}{c}2 \\
7.41 \pm 5.04\end{array}$ & $\begin{array}{c}6 \\
22.22 \pm 8.00\end{array}$ & 27 \\
\hline & $\mathrm{L}$ & $\%$ & $\begin{array}{c}23 \\
82.14 \pm 7.23\end{array}$ & $\begin{array}{c}3 \\
10.71 \pm 5.84\end{array}$ & $\begin{array}{c}2 \\
7.14 \pm 4.86\end{array}$ & 28 \\
\hline & 計 & $\%$ & $\begin{array}{c}42 \\
76.36 \pm 5.72\end{array}$ & $\begin{array}{c}5 \\
9.09 \pm 3.87\end{array}$ & $\begin{array}{c}8 \\
14.55 \pm 4.75\end{array}$ & 55 \\
\hline
\end{tabular}

として側切歯に多くみられるものであるが，現代日本人 では約50\%認められるといわれているが，広田弥生式人 についても約 $49 \%$ 認められた。

側切夹の犬夹化について

上顎では1.7\%，下顎では5.6\%と下顎の方が多く，現 代日本人については上顎で $21.6 \%$ ，下顎で $5 \%$ (上条) である，下顎では変わりないが上顎では著しく差が認め られる。

(2) 小田雨部

\section{上顎小曰雬の咬合面溝の形態}

前述の分類にしたがってその出現頻度をみると表 19 のごとくである、A型が最も基本的な形態で $\mathbf{E}$ 型が最も 退化の進行したあのであるが，P1においてはAが78％ で大部分を示しており次でBの17\%，C以下はきわめて 少ないのに対して，P 2 ではC が44\% で最む多く次いで A， Bの順序でD，Eもわずかではあるが認められる。
すなわち $\mathrm{P}_{1}$ よりあ $\mathrm{P}_{2}$ の方が退化が進んでいる。これを 著者等の現代日本人と比較すれば $\mathrm{P}_{1}$ ではAが約 $57 \%$ で 最も多いが広田弥生式人よりも少なくなって抢り, 反対 にB以下は現代日本人に多くなっており，現代日本人の 方がやや退化を示している，P2ではCが約62\%で最む 多く、次いで $\mathrm{B}, \mathrm{D}, \mathrm{E}$ で A が最も少なく $\mathrm{P}_{1}$ と同様に 睍代日本人の方がやや退化を示しているようである。

\section{上顎小臼歯の介在結節}

近心辺縁隆線_上に出現するもので十，士およびー上分 けてその頻度を調べたものが表 20である．P1 1 は土が大 部分でーのあのは非常に少ない， $\mathbf{P}_{\mathbf{2}}$ は一が大部分で+ が非常に少ない，現代日本人とほぼ同様な傾向を示して いる。

\section{上顎小巨歯の㐘根数}

現代日本人の上顎小曰歯の歯根数は $\mathrm{P}_{\mathbf{1}}$ では藤田に よれば単根 $59 \%$, 不完全二根分岐 $23 \%$, 完全二根分岐 
上顎小四蒾咬合面 の 清 型

\begin{tabular}{|c|c|c|c|c|c|c|c|c|c|}
\hline \multicolumn{3}{|c|}{ 型 } & $\mathbf{A}$ & B & C & D & $E$ & 合 & 計 \\
\hline \multirow{3}{*}{$P_{1}$} & $\mathbf{R}$ & $\begin{array}{l}\mathrm{N} \\
\%\end{array}$ & $\begin{array}{c}41 \\
69.49 \pm 5.99\end{array}$ & $\begin{array}{c}13 \\
22.03 \pm 5.73\end{array}$ & 0 & 0 & $\begin{array}{c}5 \\
8.47 \pm 3.62\end{array}$ & 59 & \\
\hline & L & $\begin{array}{l}\mathrm{N} \\
96\end{array}$ & $\begin{array}{c}46 \\
86.79 \pm 4.65\end{array}$ & $\begin{array}{c}6 \\
11.32 \pm 4.35\end{array}$ & 0 & 0 & $\begin{array}{c}1 \\
1.89 \pm 1.87\end{array}$ & 53 & \\
\hline & 計 & $\begin{array}{l}\mathrm{N} \\
\%\end{array}$ & $\begin{array}{c}87 \\
77.68 \pm 4.17\end{array}$ & $\begin{array}{c}19 \\
16.96 \pm 3.54\end{array}$ & 0 & 0 & $\begin{array}{c}6 \\
5.36 \pm 2.12\end{array}$ & 112 & \\
\hline \multirow{3}{*}{$\mathbf{P}_{2}$} & $\mathbf{R}$ & $\begin{array}{l}\mathrm{N} \\
\%\end{array}$ & $\begin{array}{c}12 \\
26.67 \pm 6.59\end{array}$ & $\begin{array}{c}13 \\
28.89 \pm 6.75\end{array}$ & $\begin{array}{c}17 \\
37.78 \pm 7.22\end{array}$ & $\begin{array}{c}2 \\
4.44 \pm 3.07\end{array}$ & $\begin{array}{c}1 \\
2.22 \pm 2.19\end{array}$ & 45 & \\
\hline & L & $\begin{array}{l}\mathrm{N} \\
\%\end{array}$ & $\begin{array}{c}11 \\
26.19 \pm 6.78\end{array}$ & $\begin{array}{c}9 \\
21.43 \pm 6.33\end{array}$ & $\begin{array}{c}21 \\
50.00 \pm 7.71\end{array}$ & 0 & $\begin{array}{c}1 \\
2.38 \pm 2.35\end{array}$ & 42 & \\
\hline & 計 & $\begin{array}{l}\mathrm{N} \\
\%\end{array}$ & $\begin{array}{c}23 \\
26.44 \pm 4.72\end{array}$ & $\begin{array}{c}22 \\
25.29 \pm 4.66\end{array}$ & $\begin{array}{c}38 \\
43.68 \pm 5.31\end{array}$ & $\begin{array}{c}2 \\
2.30 \pm 1.60\end{array}$ & $\begin{array}{c}2 \\
2.30 \pm 1.60\end{array}$ & 87 & \\
\hline
\end{tabular}

上顎小目歯の介在結節の出現頻度

\begin{tabular}{|c|c|c|c|c|c|c|}
\hline & & & - & \pm & + & 合 \\
\hline \multirow{3}{*}{$P_{1}$} & $\mathbf{R}$ & $\begin{array}{l}\mathrm{N} \\
\%\end{array}$ & $\begin{array}{c}2 \\
4.00 \pm 2.77\end{array}$ & $\begin{array}{c}32 \\
64.00 \pm 6.88\end{array}$ & $\begin{array}{c}16 \\
32.00 \pm 6.59\end{array}$ & 50 \\
\hline & L & $\begin{array}{l}\mathrm{N} \\
\%\end{array}$ & $\begin{array}{c}5 \\
10.64 \pm 4.49\end{array}$ & $\begin{array}{c}31 \\
65.96 \pm 6.91\end{array}$ & $\begin{array}{c}11 \\
23.40 \pm 6.17\end{array}$ & 47 \\
\hline & 計 & $\begin{array}{l}\mathrm{N} \\
\%\end{array}$ & $\begin{array}{c}7 \\
9.22 \pm 2.93\end{array}$ & $\begin{array}{c}63 \\
64.95 \pm 4.84\end{array}$ & $\begin{array}{c}27 \\
27.84 \pm 4.55\end{array}$ & 97 \\
\hline \multirow{3}{*}{$\mathrm{P}_{2}$} & $\mathbf{R}$ & $\begin{array}{l}\mathrm{N} \\
\%\end{array}$ & $\begin{array}{c}23 \\
65.71 \pm 8.02\end{array}$ & $\begin{array}{c}10 \\
28.57 \pm 7.63\end{array}$ & $\begin{array}{c}2 \\
5.71 \pm 3.92\end{array}$ & 35 \\
\hline & L & $\begin{array}{l}\mathrm{N} \\
96\end{array}$ & $\begin{array}{c}18 \\
58.06 \pm 8.86\end{array}$ & $\begin{array}{c}13 \\
41.94 \pm 8.86\end{array}$ & 0 & 31 \\
\hline & 計 & $\begin{array}{l}\mathbf{N} \\
\%\end{array}$ & $\begin{array}{c}41 \\
62.12 \pm 5.97\end{array}$ & $\begin{array}{c}23 \\
34.85 \pm 5.86\end{array}$ & $\begin{array}{c}2 \\
3.03 \pm 2.10\end{array}$ & 66 \\
\hline
\end{tabular}

13\%，また上条によれば単根58\%，不完全二根分岐33.6 $\%$ ，完全二根分岐8.4\%であるとされ，かなりの二根性 歯牙が認められるが，P 2 に打いでは単根歯が 95\%で二 根歯は稀である，広田弥生式人では表 21 のごとく $\mathrm{P}_{\mathbf{1}}$ で は二根歯が約60\%，P 2 では二根菡がわずが $2.4 \%$ ， 現代日本人と比べて $P_{1}$ では二根歯がやや多く， $P_{2}$ では
やや少ないようである。

\section{下顎小臼菡の咬頭数}

表22に示すごとく $\mathbf{P}_{1}$ では大部分が 2 または 2 一であ って3拈よび 3ーはきわぬて少ない．現代日本人につい てあほぼ同様のことがいえる， $\mathrm{P}_{2}$ については3が最も 多く58\%であるのに対して，著者等の現代日本人では 2 


\begin{tabular}{|c|c|c|c|c|c|}
\hline & & & 2 & 1 & 合 \\
\hline \multirow{3}{*}{$P_{1}$} & $\mathbf{R}$ & $\%$ & $\begin{array}{c}18 \\
62.07 \pm 9.01\end{array}$ & $\begin{array}{c}11 \\
37.93 \pm 9.01\end{array}$ & 29 \\
\hline & L & $\mathbf{N}$ & $\begin{array}{c}14 \\
58.33 \pm 10.06\end{array}$ & $\begin{array}{c}10 \\
41.67 \pm 10.06\end{array}$ & 24 \\
\hline & 計 & $\%$ & $\begin{array}{c}32 \\
60.38 \pm 6.71\end{array}$ & $\begin{array}{c}21 \\
39.62 \pm 6.71\end{array}$ & 53 \\
\hline \multirow{3}{*}{$\mathrm{P}_{2}$} & $\mathrm{R}$ & $\mathrm{N}$ & $\begin{array}{c}1 \\
4.35 \pm 4.25\end{array}$ & $\begin{array}{c}22 \\
95.65 \pm 4.25\end{array}$ & 23 \\
\hline & L & $\%$ & 0 & $\begin{array}{c}19 \\
100.00\end{array}$ & 19 \\
\hline & 計 & $\%$ & $\begin{array}{c}1 \\
2.38 \pm 2.35\end{array}$ & $\begin{array}{c}41 \\
97.62 \pm 2.35\end{array}$ & 42 \\
\hline
\end{tabular}

下顎 小四歯 の 咬頭 数

\begin{tabular}{|c|c|c|c|c|c|c|c|}
\hline \multicolumn{3}{|c|}{ 型 } & $2-$ & 2 & $3-$ & 3 & 計 \\
\hline \multirow{3}{*}{$P_{1}$} & $\mathbf{R}$ & $\begin{array}{l}\mathrm{N} \\
\%\end{array}$ & $\begin{array}{c}20 \\
26.67 \pm 5.10\end{array}$ & $\begin{array}{c}51 \\
68.00 \pm 5.38\end{array}$ & $\begin{array}{c}2 \\
2.67 \pm 1.86\end{array}$ & $\begin{array}{c}2 \\
2.67 \pm 1.86\end{array}$ & 75 \\
\hline & $\mathbf{L}$ & $\begin{array}{l}\mathrm{N} \\
96\end{array}$ & $\begin{array}{c}19 \\
30.65 \pm 5.85\end{array}$ & $\begin{array}{c}41 \\
66.13 \pm 6.01\end{array}$ & 0 & $\begin{array}{c}2 \\
3.23 \pm 2.24\end{array}$ & 62 \\
\hline & 計 & $\begin{array}{l}\mathrm{N} \\
\%\end{array}$ & $\begin{array}{c}39 \\
28.47 \pm 4.15\end{array}$ & $\begin{array}{c}92 \\
67.15 \pm 4.01\end{array}$ & $\begin{array}{c}2 \\
1.46 \pm 1.02\end{array}$ & $\begin{array}{c}4 \\
2.92 \pm 1.43\end{array}$ & 137 \\
\hline \multirow{3}{*}{$\mathbf{P}_{2}$} & $\mathbf{R}$ & $\begin{array}{l}\mathrm{N} \\
96\end{array}$ & 0 & $\begin{array}{c}20 \\
30.30 \pm 5.65\end{array}$ & $\begin{array}{c}6 \\
9.09 \pm 3.53\end{array}$ & $\begin{array}{c}40 \\
60.61 \pm 6.01\end{array}$ & 66 \\
\hline & L & $\begin{array}{l}\mathrm{N} \\
96\end{array}$ & 0 & $\begin{array}{c}24 \\
36.92 \pm 5.98\end{array}$ & $\begin{array}{c}5 \\
7.69 \pm 3.03\end{array}$ & $\begin{array}{c}36 \\
55.38 \pm 6.16\end{array}$ & 65 \\
\hline & 計 & $\begin{array}{l}\mathbf{N} \\
\%\end{array}$ & 0 & $\begin{array}{c}44 \\
33.59 \pm 4.12\end{array}$ & $\begin{array}{c}11 \\
\text { 8. } 40 \pm 2.42\end{array}$ & $\begin{array}{c}76 \\
58.02 \pm 4.31\end{array}$ & 131 \\
\hline
\end{tabular}

が約46\%で最む多く，3 は約34\%となっており，広田弥 生式人とは異なった傾向を示している。

下顎小臼歯の咬合面满の形態

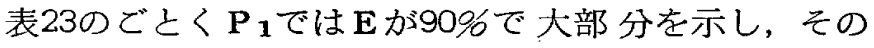
他の型は非常に少ない，P 2 ではA が42\%で最む多く， 次いで B，C，Dの順でEはなく，P1 とは全く逆であ

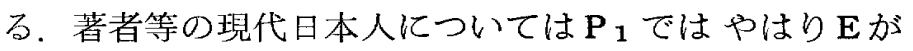

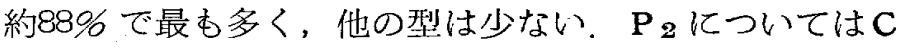
が約 $47 \%$ で最む多く次いでB，Aの順序となっており， 広田弥生式人の $\mathrm{A} か ゙$ 最も多い点之刘比してかなりの相異 を見せている。

下顎小臼歯咬合面の連合隆線 


\begin{tabular}{|c|c|c|c|c|c|c|c|c|}
\hline 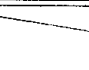 & 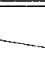 & & $\mathbf{A}$ & B & C & D & $\mathbf{E}$ & 計 \\
\hline \multirow{3}{*}{$P_{1}$} & $\mathbf{R}$ & $\begin{array}{l}\mathrm{N} \\
\%\end{array}$ & 0 & $\begin{array}{c}1 \\
1.75 \pm 1.73\end{array}$ & $\begin{array}{c}1 \\
1.75 \pm 1.73\end{array}$ & $\begin{array}{c}5 \\
8.77 \pm 3.74\end{array}$ & $\begin{array}{c}50 \\
87.72 \pm 4.34\end{array}$ & 57 \\
\hline & L & $\begin{array}{l}\mathrm{N} \\
\%\end{array}$ & 0 & 0 & $\begin{array}{c}2 \\
4.17 \pm 2.88\end{array}$ & $\begin{array}{c}1 \\
2.08 \pm 2.06\end{array}$ & $\begin{array}{c}45 \\
93.75 \pm 3.49\end{array}$ & 48 \\
\hline & 訫 & $\begin{array}{l}\mathrm{N} \\
\mathscr{6}\end{array}$ & 0 & $\begin{array}{c}1 \\
0.95 \pm 0.94\end{array}$ & $\begin{array}{c}3 \\
2.86 \pm 1.62\end{array}$ & $\begin{array}{c}6 \\
5.71 \pm 2.26\end{array}$ & $\begin{array}{c}95 \\
90.48 \pm 2.86\end{array}$ & 105 \\
\hline \multirow{3}{*}{$\mathrm{P}_{2}$} & $\mathbf{R}$ & $\begin{array}{l}\mathrm{N} \\
\%\end{array}$ & $\begin{array}{c}24 \\
46.15 \pm 6.91\end{array}$ & $\begin{array}{c}11 \\
21.15 \pm 5.66\end{array}$ & $\begin{array}{c}7 \\
13.46 \pm 4.73\end{array}$ & $\begin{array}{c}10 \\
19.23 \pm 5.47\end{array}$ & 0 & 52 \\
\hline & L & $\begin{array}{l}\mathrm{N} \\
\%\end{array}$ & $\begin{array}{c}20 \\
37.04 \pm 6.57\end{array}$ & $\begin{array}{c}9 \\
16.67 \pm 5.07\end{array}$ & $\begin{array}{c}9 \\
16.67 \pm 5.07\end{array}$ & $\begin{array}{c}16 \\
29.63 \pm 6.21\end{array}$ & 0 & 54 \\
\hline & 計 & $\begin{array}{l}\mathrm{N} \\
\%\end{array}$ & $\begin{array}{c}44 \\
41.51 \pm 4.78\end{array}$ & $\begin{array}{c}20 \\
18.87 \pm 3.80\end{array}$ & $\begin{array}{c}16 \\
15.09 \pm 3.47\end{array}$ & $\begin{array}{c}26 \\
24.53 \pm 4.17\end{array}$ & 0 & 106 \\
\hline
\end{tabular}

下䫟小臼歯咬合面の連合隆線

\begin{tabular}{|c|c|c|c|c|c|}
\hline & & & + & - & 合 \\
\hline \multirow{3}{*}{$P_{1}$} & $\mathbf{R}$ & $\begin{array}{l}\mathrm{N} \\
\%\end{array}$ & $\begin{array}{c}59 \\
90.77 \pm 3.59\end{array}$ & $\begin{array}{c}6 \\
9.23 \pm 3.59\end{array}$ & 65 \\
\hline & $\mathbf{L}$ & $\begin{array}{l}\mathrm{N} \\
\%\end{array}$ & $\begin{array}{c}50 \\
96.15 \pm 2.66\end{array}$ & $\begin{array}{c}2 \\
3.85 \pm 2.66\end{array}$ & 52 \\
\hline & 計 & $\begin{array}{l}\mathrm{N} \\
\%\end{array}$ & $\begin{array}{c}109 \\
93.16 \pm 2.33\end{array}$ & $\begin{array}{c}8 \\
6.84 \pm 2.33\end{array}$ & 117 \\
\hline \multirow{3}{*}{$\mathrm{P}_{2}$} & $\mathbf{R}$ & $\begin{array}{l}\mathrm{N} \\
96\end{array}$ & $\begin{array}{c}1 \\
2.00 \pm 1.98\end{array}$ & $\begin{array}{c}49 \\
98.00 \pm 1.98\end{array}$ & 50 \\
\hline & L & $\begin{array}{l}\mathrm{N} \\
\%\end{array}$ & $\begin{array}{c}1 \\
1.82 \pm 1.80\end{array}$ & $\begin{array}{c}54 \\
98.18 \pm 1.80\end{array}$ & 55 \\
\hline & 計 & $\begin{array}{l}\mathrm{N} \\
\%\end{array}$ & $\begin{array}{c}2 \\
1.90 \pm 1.33\end{array}$ & $\begin{array}{c}103 \\
98.10 \pm 1.33\end{array}$ & 105 \\
\hline
\end{tabular}

これは咬合面の煩舌両咬頭の中心隆線が中心溝を切断 して連合した状態を示しているすのであって，表24のご とく $\mathrm{P}_{1}$ では93\%に連合隆線が認め゙られ， $\mathrm{P}_{2}$ にはわずか に1.9\%しか認められない．現代因本人でもほぼ同様の 傾向がみられるが，現代日本人では $\mathrm{P}_{\mathbf{1}}$ で約 $84 \%$ とやや 少なくなっているようである.
(3) 上顎大曰歯部 咬頭型について

Dahllberg の分類は Hypocone の退化の状態にした がって四型に分類したものであるが，表25に示すごとく 広田弥生式人は $\mathbf{M}_{1}$ では 4 型が100\%， $\mathbf{M}_{2}$ では70\%の出 現頻度を示しているのに対して $\mathbf{M}_{3}$ では 4 型はわずかに 11.9\% 上少なく，逆に3型が最も多く $47.6 \%$ で，更には 

広田弥生式人上顎大田蒾の咬頭型（DAHLBERG の分類）

\begin{tabular}{|c|c|c|c|c|c|c|c|}
\hline & & & 4 & $4-$ & $3+$ & 3 & 数 \\
\hline \multirow{3}{*}{$\mathbf{M}_{1}$} & $\mathbf{R}$ & $\begin{array}{l}\mathbf{N} \\
\%\end{array}$ & $\begin{array}{c}67 \\
100.00\end{array}$ & & & & 67 \\
\hline & $\mathbf{L}$ & $\begin{array}{l}\mathbf{N} \\
\%\end{array}$ & $\begin{array}{c}54 \\
100.00\end{array}$ & & & & 54 \\
\hline & 計 & $\begin{array}{l}\mathrm{N} \\
\%\end{array}$ & $\begin{array}{c}121 \\
100.00\end{array}$ & & & & 121 \\
\hline \multirow{3}{*}{$\mathbf{M}_{2}$} & $\mathbf{R}$ & $\begin{array}{l}\mathrm{N} \\
\%\end{array}$ & $\begin{array}{c}38 \\
67.85 \pm 6.24\end{array}$ & $\begin{array}{c}15 \\
26.79 \pm 5.91\end{array}$ & $\begin{array}{c}3 \\
5.36 \pm 3.00\end{array}$ & & 56 \\
\hline & L & $\begin{array}{l}\mathrm{N} \\
96\end{array}$ & $\begin{array}{c}46 \\
71.88 \pm 5.62\end{array}$ & $\begin{array}{c}16 \\
25.00 \pm 5.41\end{array}$ & $\begin{array}{c}2 \\
\text { 3. } 13 \pm 2.17\end{array}$ & & 64 \\
\hline & 計 & $\begin{array}{l}\mathbf{N} \\
96\end{array}$ & $\begin{array}{c}84 \\
70.00 \pm 4.18\end{array}$ & $\begin{array}{c}31 \\
25.83 \pm 3.99\end{array}$ & $\begin{array}{c}5 \\
4.17 \pm 1.82\end{array}$ & & 120 \\
\hline \multirow{3}{*}{$\mathbf{M}_{\mathbf{3}}$} & $\mathbf{R}$ & $\begin{array}{l}\mathrm{N} \\
\% 6\end{array}$ & $\begin{array}{c}4 \\
9.30 \pm 4.40\end{array}$ & $\begin{array}{c}8 \\
18.60 \pm 5.93\end{array}$ & $\begin{array}{c}4 \\
9.30 \pm 4.40\end{array}$ & $\begin{array}{c}27 \\
62.79 \pm 7.37\end{array}$ & 43 \\
\hline & L & $\begin{array}{l}\mathbf{N} \\
\%\end{array}$ & $\begin{array}{c}6 \\
14.63 \pm 5.51\end{array}$ & $\begin{array}{c}9 \\
21.95 \pm 6.46\end{array}$ & $\begin{array}{c}4 \\
9.76 \pm 4.63\end{array}$ & $\begin{array}{c}22 \\
53.66 \pm 7.79\end{array}$ & 41 \\
\hline & 計 & $\begin{array}{l}\mathrm{N} \\
\%\end{array}$ & $\begin{array}{c}10 \\
11.90 \pm 3.72\end{array}$ & $\begin{array}{c}17 \\
20.24 \pm 4.38\end{array}$ & $\begin{array}{c}8 \\
9.52 \pm 3.20\end{array}$ & $\begin{array}{c}49 \\
58.33 \pm 5.37\end{array}$ & 84 \\
\hline
\end{tabular}

この四型以外に Metacone あ退化消失して 2 咬頭と なったものが10.7\%よなっている，表26では現代日本人 ならびに他人種との比較を示したあのであるが，現代 日本人では $M_{1}$ ではむちろん 4 型が最あ多いのではある が，その頻度は82.3\%と少なくなり， $\mathbf{M}_{\mathbf{2}}$ では小住の10 $\%$ ，鈴木等の $4 \%$ と著しく差異を示している， $\mathbf{M}_{\mathbf{2}}$ では 現代日本人は 4 一型が最も多くなっている。また三津打 よび土井ケ浜弥生式人とはほぼ同じような傾向が認めら れる。 M3 では現代日本人の 3 型が83\%でてれも広田弥 生式人の方が少ない.すすおち咬頭の退化は㕕田弥生式 人よりも現代日本人に扤いてはかなり進んでいることが 認められる。特に $\mathbf{M}_{2}$ で著明である。

畨冠の近遠心的圧平の状態

表27に示すごとく $\mathbf{M}_{1}$ では近遠心的圧平を示すものは ほとんどなく， $\mathbf{M}_{\mathbf{2}}$ では著明なあの6\%，やや認められ るもの21\%でかなりの圧平型がみられる。.Msでは著明 なもの8\%やや認められるあの12\%となっている．現 代日本人に比べる亡表28のごとくで圧平型（十，士）が
$\mathbf{M}_{1}, \mathbf{M}_{2}, \mathbf{M}_{3}$ のいずれについても広田弥生式人の方が 多くなっており特に $\mathbf{M}_{\mathbf{2}}$ では著明である。 蒾根数

原則としては3根であるが，各根が退化隔合して 2 1 根となるものがみられ，特に $\mathbf{M}_{\mathbf{1}}$ より $\mathbf{M}_{\mathbf{2}}, \mathbf{M}_{\mathbf{3}}$ へと 著しくなっている. 表290ごとく広田弥生式人は 3 根が

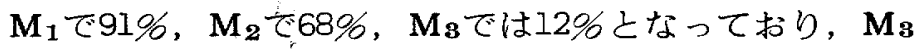
では1根が67\%亡最む多くなっている，現代日本人と比 較してそれほよ゙大きな差はないようである。

過剰結節の出現状態

カラベリー結節の出現頻度は表30に示すごとく $\mathbf{M}_{\mathbf{1}}$ で は16.5\%, $\mathbf{M}_{\mathbf{2}}$ では0.8\%, $\mathbf{M}_{3}$ では14.3\%で $\mathbf{M}_{1}\left\llcorner\mathbf{M}_{3}\right.$ に 多く現代日本人に比べて $\mathbf{M}_{3}$ では特に多いようである.

日旁結節は $\mathbf{M}_{1}$ で121例中 1 例， $\mathbf{M}_{\mathbf{2}}$ で121例中 2 例また Maでは84例中 1 例で非常に少ない，目後結節は $\mathbf{M}_{\mathbf{3}}$ で 1 例を認める。

(4) 下顎大扫崡部 咬頭数 


\begin{tabular}{|c|c|c|c|c|c|c|c|c|c|c|c|c|c|c|c|}
\hline \multirow{2}{*}{ 人種別 } & \multicolumn{5}{|c|}{$\mathbf{M}_{1}$} & \multicolumn{5}{|c|}{$\mathbf{M}_{2}$} & \multicolumn{5}{|c|}{$\mathrm{M}_{3}$} \\
\hline & 霜数 & 4 & $4-\mid$ & $3+\mid$ & 3 & 歯数 & 4 & $|4-|$ & $3+\mid$ & 3 & 雪数 & 4 & $4-1$ & $3+1$ & 3 \\
\hline $\begin{array}{l}\text { East Greenland Eskimo Skulls } \\
\text { (PEDERSEN) }\end{array}$ & 59 & 100.0 & & & & 53 & 64.0 & & & 36.0 & & & & & \\
\hline $\begin{array}{l}\text { East Greenland living Eskimo } \\
\text { (PEDERSEN) }\end{array}$ & 186 & 100.0 & & & & 181 & 65.7 & & & 34.3 & & & & & \\
\hline $\begin{array}{l}\text { Pecos Indians } \\
\text { (NELSON) }\end{array}$ & 285 & 98.9 & & 1.1 & & 278 & 66.1 & & 32.1 & 1.4 & & & & & \\
\hline $\begin{array}{l}\text { Texas Indians } \\
\text { (GOLDSTEIN) }\end{array}$ & 270 & 99.6 & & & & 228 & 59.3 & & & 39.4 & & & & & \\
\hline $\begin{array}{l}\text { Pima Indian } \\
\text { (DAHLBERG) }\end{array}$ & 322 & 99.4 & 0.6 & & & 182 & 11.0 & 47.0 & 23.0 & 19.0 & & & & & \\
\hline $\begin{array}{l}\text { Melanesian } \\
\text { (DAHLBERG) }\end{array}$ & 266 & 98.0 & 2.0 & & & 216 & 50.0 & 37.0 & & 13.0 & & & & & \\
\hline $\begin{array}{l}\text { American White Children } \\
\text { (DAHLBERG) }\end{array}$ & 53 & 69.0 & 29.0 & 2.0 & & 11 & & 55.0 & 27.0 & 18.0 & & & & & \\
\hline $\begin{array}{l}\text { American White } \\
\text { (HELLMAN) }\end{array}$ & 106 & 95. & 3.0 & & 2.0 & 92 & 38.0 & 20.0 & & 42.0 & & & & & \\
\hline $\begin{array}{l}\text { 日本 } \\
\text { (鈴木, 酒井) }\end{array}$ & 1774 & 81.2 & 18.1 & 0.6 & 0.1 & 1774 & 4.2 & 53.4 & 427.0 & $\mid 15.4$ & & & & & \\
\hline $\begin{array}{l}\text { American White Races } \\
\text { (武 久) }\end{array}$ & 331 & 90.1 & & 6.9 & 3.0 & 352 & 32.4 & & 38.6 & 29.0 & & & & & \\
\hline (小本 住) & 1753 & 83.5 & 15.2 & 0.4 & 0.9 & 1085 & 10.4 & 452.7 & 78.4 & 18.4 & 162 & 0.6 & 11.1 & 4.9 & \\
\hline 広田弥生式時代人 & 121 & 100.0 & & & & 120 & 70.0 & 25.8 & 4.2 & & 84 & $11.9 \%$ & 20.2 & 9.5 & 58 \\
\hline $\begin{array}{l}\text { 土茾ケ淘弥生式時代人 } \\
\text { (誒) }\end{array}$ & 77 & 100.0 & & & & 52 & 71.2 & & & 28.8 & 19 & 22.3 & & & 77.8 \\
\hline $\begin{array}{l}\text { 三津弥生式時代人 } \\
\text { (大 野) }\end{array}$ & 16 & 93.7 & & & 6.3 & 20 & 100,0 & & & & & 33.3 & & & \\
\hline
\end{tabular}

広田弥生式人上䫟大臼崡々冠の压平型出現頻度

\begin{tabular}{|c|c|c|c|c|c|c|}
\hline & & & + & \pm & - & 総 \\
\hline \multirow{3}{*}{$\mathbf{M}_{1}$} & $\mathbf{R}$ & $\begin{array}{l}\mathrm{N} \\
\mathscr{6}\end{array}$ & & $\begin{array}{c}2 \\
\text { 3. } 17 \pm 2.20\end{array}$ & $\begin{array}{c}61 \\
96.83 \pm 2.20\end{array}$ & 63 \\
\hline & $\mathbf{L}$ & $\begin{array}{l}\mathrm{N} \\
\%\end{array}$ & & & $\begin{array}{c}56 \\
100.00\end{array}$ & 56 \\
\hline & 計 & $\begin{array}{l}\mathrm{N} \\
\%\end{array}$ & & $\begin{array}{c}2 \\
1.68 \pm 1.17\end{array}$ & $\begin{array}{c}117 \\
98.32 \pm 1.17\end{array}$ & 119 \\
\hline \multirow{3}{*}{$\mathrm{M}_{2}$} & $\mathrm{R}$ & $\begin{array}{l}\mathrm{N} \\
\%\end{array}$ & $\begin{array}{c}3 \\
5.45 \pm 3.06\end{array}$ & $\begin{array}{c}10 \\
18.18 \pm 5.20\end{array}$ & $\begin{array}{c}42 \\
76.36 \pm 5.72\end{array}$ & 55 \\
\hline & L & $\begin{array}{l}\mathrm{N} \\
\% 6\end{array}$ & $\begin{array}{c}4 \\
6.45 \pm 3.11\end{array}$ & $\begin{array}{c}15 \\
24.19 \pm 5.43\end{array}$ & $\begin{array}{c}43 \\
69.35 \pm 5.58\end{array}$ & 62 \\
\hline & 計 & $\begin{array}{l}\mathrm{N} \\
\%\end{array}$ & $\begin{array}{c}7 \\
5.98 \pm 2.19\end{array}$ & $\begin{array}{c}25 \\
21.37 \pm 3.78\end{array}$ & $\begin{array}{c}85 \\
72.65 \pm 4.12\end{array}$ & 117 \\
\hline
\end{tabular}




\begin{tabular}{c|c|c|c|c|c|c} 
& $\mathbf{R}$ & $\mathbf{N}$ & 4 & 3 & 35 & \\
$\mathbf{M 3}$ & $\%$ & $9.52 \pm 4.52$ & $7.14 \pm 3.96$ & $83.33 \pm 5.75$ & 42 \\
\cline { 2 - 6 } & $\mathbf{L}$ & $\mathbf{N}$ & 3 & 7 & 31 & 41 \\
& $\%$ & $7.32 \pm 4.06$ & $17.07 \pm 5.87$ & $75.61 \pm 6.70$ & \\
\hline \multirow{2}{*}{ 計 } & $\mathbf{N}$ & 7 & 10 & 66 & 83 \\
\hline
\end{tabular}

上顎大曰霜歯冠の圧平型の出現状態比較

\begin{tabular}{|c|c|c|c|c|c|c|c|}
\hline & & \multicolumn{2}{|c|}{$\mathbf{M}_{1}$} & \multicolumn{2}{|c|}{$\mathbf{M}_{2}$} & \multicolumn{2}{|c|}{$\mathrm{M}_{3}$} \\
\hline & & 圧平型 & 非圧平型 & 圧 平 型 & 非圧平型 & 压平 型 & 非圧平型 \\
\hline \multirow{2}{*}{ 広田弥生式人 } & $\mathbf{N}$ & 2 & 117 & 32 & 85 & 17 & 66 \\
\hline & $\%$ & 1.7 & 98.3 & 27.3 & 72.7 & 20.5 & 79.5 \\
\hline 小 & $\mathbf{N}$ & 17 & 1730 & 99 & 985 & 10 & 52 \\
\hline （現代日本人） & $\%$ & 1.0 & 99.0 & 9. I & 90.9 & 16.1 & 83.9 \\
\hline 鈴木・酒井 & $\mathbf{N}$ & 5 & 510 & 34 & 449 & & \\
\hline （現代日本人） & 96 & 1.0 & 99.0 & 7.0 & 93.0 & & \\
\hline
\end{tabular}

上顎大臼歯の歯根数比較 (\%)

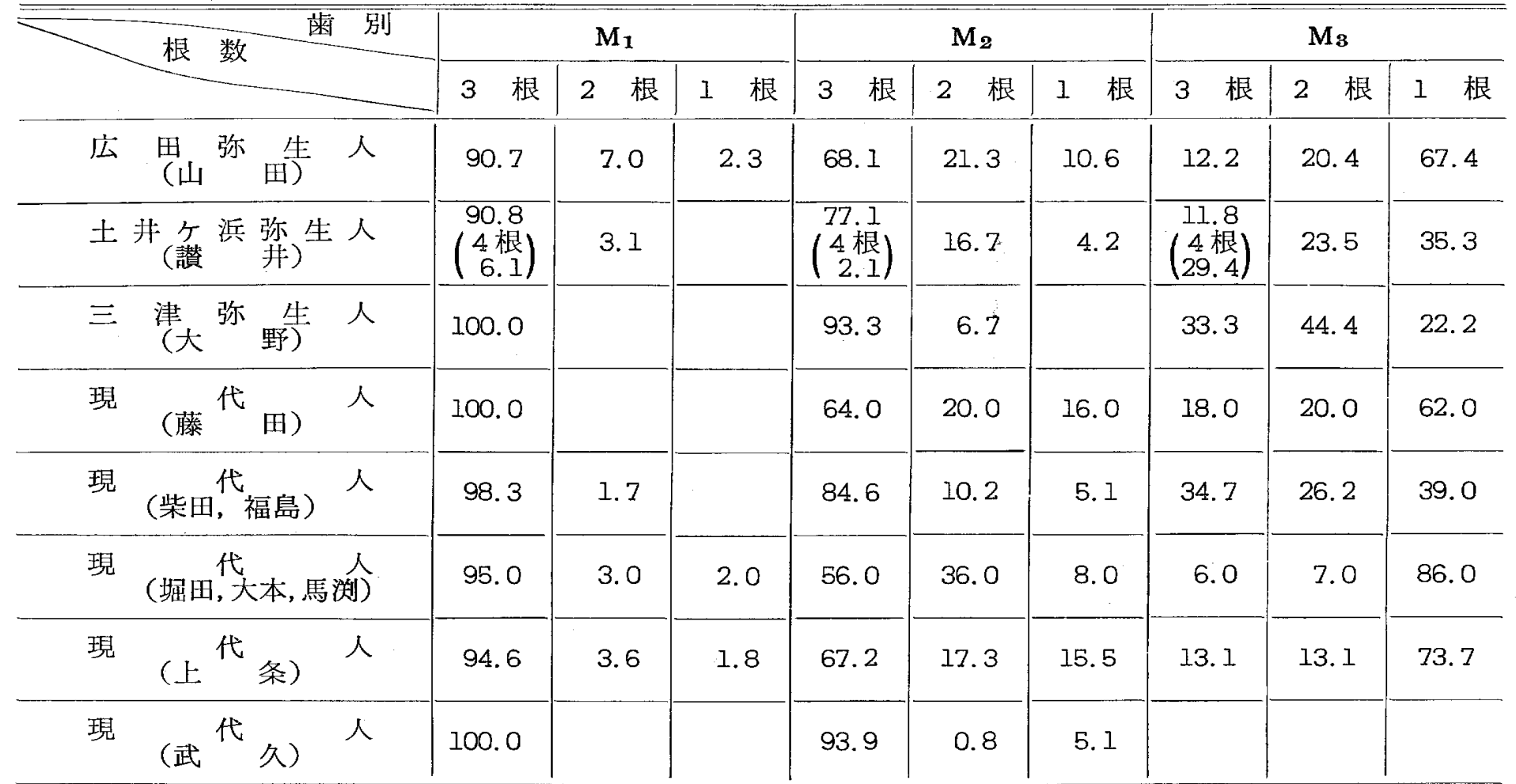


カラベリー結節出現頻度の比較

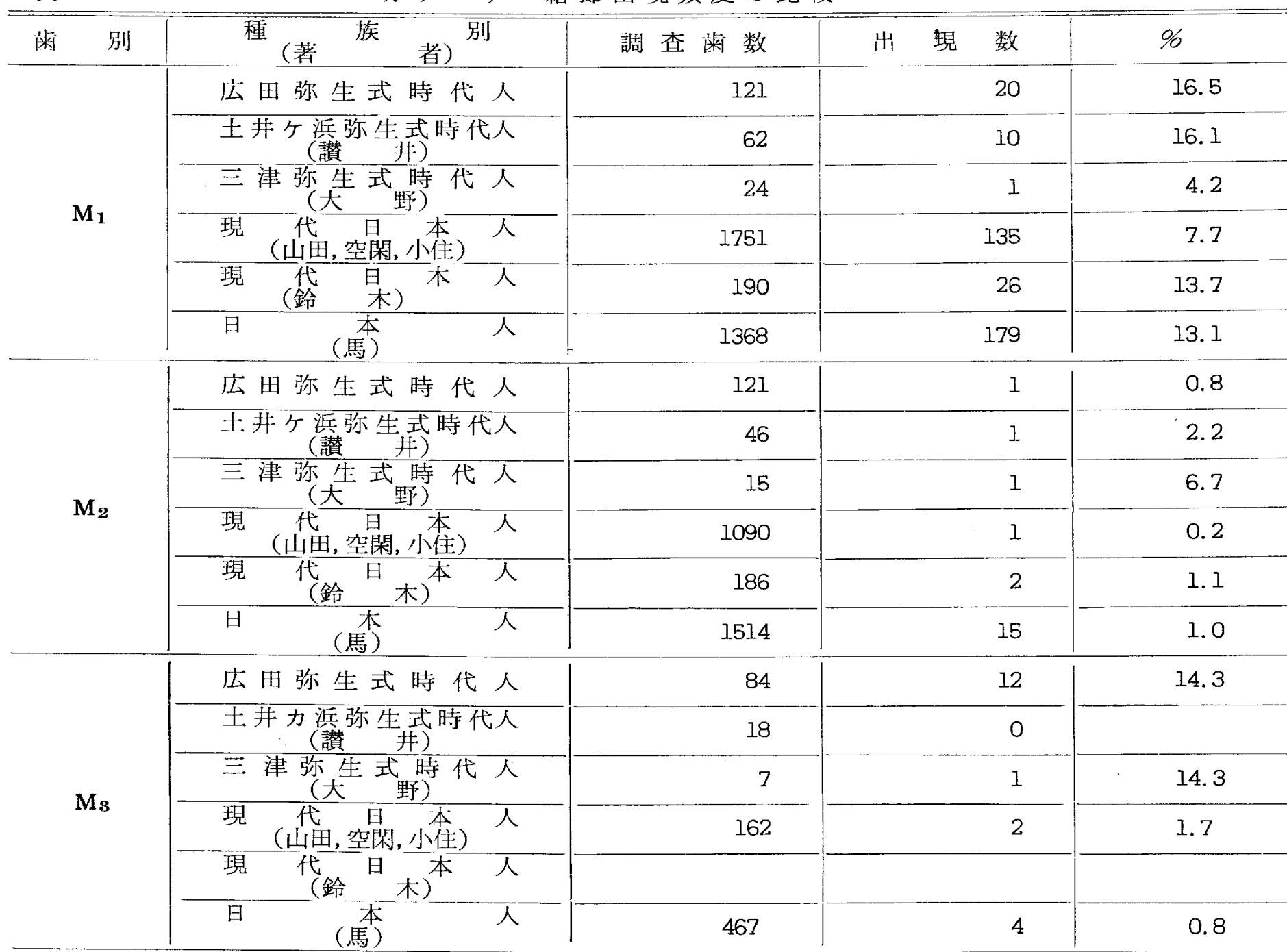

表31 下顎大巨歯の咬頭数

\begin{tabular}{|c|c|c|c|c|}
\hline & & & 5 咬 頭 & 4 咬 頭 \\
\hline \multirow{3}{*}{$\mathrm{M}_{1}$} & $\mathbf{R}$ & $\begin{array}{l}\mathrm{N} \\
\%\end{array}$ & $\begin{array}{c}61 \\
92.42 \pm 3.25\end{array}$ & $\begin{array}{c}5 \\
7.58 \pm 3.25\end{array}$ \\
\hline & $\mathbf{L}$ & $\begin{array}{l}\mathrm{N} \\
\%\end{array}$ & $\begin{array}{c}63 \\
96.92 \pm 2.14\end{array}$ & $\begin{array}{c}2 \\
3.08 \pm 2.14\end{array}$ \\
\hline & 計 & $\begin{array}{l}\mathrm{N} \\
96\end{array}$ & $\begin{array}{c}124 \\
94.66 \pm 1.96\end{array}$ & $\begin{array}{c}7 \\
5.34 \pm 1.96\end{array}$ \\
\hline \multirow{3}{*}{$\mathrm{M}_{2}$} & $\mathbf{R}$ & $\begin{array}{l}\mathbf{N} \\
96\end{array}$ & $\begin{array}{c}5 \\
7.69 \pm 3.30\end{array}$ & $\begin{array}{c}60 \\
92.31 \pm 3.30\end{array}$ \\
\hline & L & $\begin{array}{l}\mathrm{N} \\
\%\end{array}$ & $\begin{array}{c}13 \\
18 \cdot 84 \pm 4.70\end{array}$ & $\begin{array}{c}56 \\
81.16 \pm 4.70\end{array}$ \\
\hline & 計 & $\begin{array}{l}\mathrm{N} \\
86\end{array}$ & $\begin{array}{c}18 \\
\text { 13. } 43 \pm 2.94\end{array}$ & $\begin{array}{c}116 \\
86.57 \pm 2.94\end{array}$ \\
\hline
\end{tabular}

\begin{tabular}{c|c|c|c|c}
\hline \multirow{2}{*}{$\mathbf{M 3}$} & $\mathrm{R}$ & $\mathrm{N}$ & 5 & 29 \\
& $\%$ & $14.71 \pm 6.07$ & $85.29 \pm 6.07$ \\
\hline $\mathrm{L}$ & $\mathrm{N}$ & 11 & 28 \\
& $\%$ & $28.21 \pm 7.20$ & $71.79 \pm 7.20$ \\
\hline & $\mathrm{N}$ & 16 & 57 \\
\hline 計 & $\%$ & $21.92 \pm 4.84$ & $78.08 \pm 4.84$ \\
\hline
\end{tabular}

表31のごとく $\mathbf{M}_{1}$ では 5 咬頭㐘が $95 \%$ で大部分であ

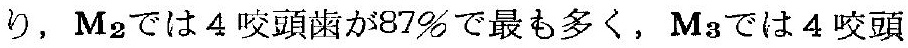
霜が $78 \%$ \%゙ある。現代日本人と比べると表 32 のごとく $\mathbf{M}_{1}$ では大差はないが， $\mathbf{M}_{2}$ および $\mathbf{M}_{3}$ では著しく4咬頭 来が多いことが特徵的である。また三津および土井ケ浜 弥生式人と比べてむ 4 咬頭蒾が特に多い. 咬合面溝の形態 
下顎大四蒾の咬頭数比較

\begin{tabular}{|c|c|c|c|c|c|c|c|c|c|}
\hline & \multicolumn{2}{|c|}{$\mathbf{M}_{1}$} & \multicolumn{3}{|c|}{$\mathrm{M}_{2}$} & \multicolumn{4}{|c|}{$\mathbf{M 3}$} \\
\hline & 5 & 4 & 6 & 5 & 4 & 6 & 5 & 4 & 3 \\
\hline 広田弥生式人 & 94.7 & 5.3 & & 13.4 & 86.6 & & 21.9 & 78.1 & \\
\hline 土井ヶ浜弥生式人 & 95.9 & 4.1 & 1.9 & 41.5 & 56.6 & 6.9 & 55.2 & 37.9 & \\
\hline 三 津 弥 生式人 & 100.0 & & & 75.0 & 25.2 & & 56.3 & 31.3 & 12.5 \\
\hline 現代日本人（小住） & 95.6 & 4.4 & & 42.3 & 57.7 & & 47.5 & 52.5 & \\
\hline
\end{tabular}

\begin{tabular}{|c|c|c|c|c|c|}
\hline & & & $\mathrm{Y}$ & + & $\mathbf{x}$ \\
\hline \multirow{6}{*}{$\mathbf{M}_{1}$} & \multirow{2}{*}{$\mathbf{R}$} & $\mathbf{N}$ & 45 & 20 & \\
\hline & & $\%$ & $69.23 \pm 5.72$ & $30.77 \pm 5.72$ & \\
\hline & \multirow{2}{*}{$\mathbf{L}$} & $\mathbf{N}$ & 51 & 14 & \\
\hline & & $\%$ & $78.46 \pm 5.10$ & $21.54 \pm 5.10$ & \\
\hline & \multirow{2}{*}{ 計 } & $\mathbf{N}$ & 96 & 34 & \\
\hline & & $\%$ & $73.85 \pm 3.86$ & $26.15 \pm 3.86$ & \\
\hline \multirow{6}{*}{$\mathbf{M}_{2}$} & \multirow{2}{*}{$\mathbf{R}$} & $\mathbf{N}$ & 3 & 53 & 8 \\
\hline & & $\%$ & $4.69 \pm 2.60$ & $82.81 \pm 4.71$ & $12.50 \pm 4.13$ \\
\hline & \multirow{2}{*}{ L } & $\mathbf{N}$ & 4 & 59 & 8 \\
\hline & & $\%$ & $5.63 \pm 2.73$ & $83.10 \pm 4.44$ & $11.27 \pm 3.75$ \\
\hline & \multirow{2}{*}{ 計 } & $\mathbf{N}$ & 7 & 112 & 16 \\
\hline & & $\%$ & 5. $19 \pm 1.90$ & $82.96 \pm 3.23$ & $11.85 \pm 2.78$ \\
\hline \multirow{6}{*}{$\mathbf{M}_{\mathbf{3}}$} & \multirow{2}{*}{$\mathbf{R}$} & $\mathrm{N}$ & & 17 & 17 \\
\hline & & $\%$ & & $50.00 \pm 8.57$ & $50.00 \pm 8.57$ \\
\hline & \multirow{2}{*}{$\mathbf{L}$} & $\mathbf{N}$ & 3 & 15 & 16 \\
\hline & & $\%$ & $8.82 \pm 4.86$ & $44.12 \pm 8.51$ & $47.06 \pm 8.56$ \\
\hline & \multirow{2}{*}{ 計 } & $\mathbf{N}$ & 3 & 32 & 33 \\
\hline & & $\%$ & $4.41 \pm 2.48$ & $47.06 \pm 6.05$ & $48.53 \pm 6.06$ \\
\hline
\end{tabular}

表33および34のごとく $\mathrm{M}_{\mathbf{1}}$ はY 型が74\%で最む多く， 現代日本人に比べると型の出現率は高い， $\mathbf{M}_{\mathbf{2}}$ は+型 が83\%で最む多くY型はわずかに $5 \%$ に過ぎない，乙れ を現代日本人に比べると小住の成績以外はすべて+型の 出現率が弥生式人に多く，現代日本人ではX型が多くな っている.MaはX型が48.5\%で+型が $47 \%$ となってお り現代日本人とは大差はない.

咬頭数と溝型との関連性について

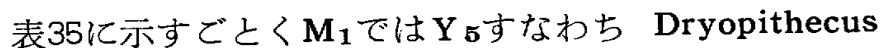
Pattern が70\%で最む多く, $\mathbf{M}_{2}$ では+^が75.4\%で最も

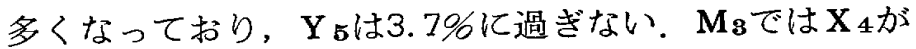
39.7\%, 次いで+4が36.8\%でY5は3\%に過ぎない.と れを現代日本人および他人種と比較したものが表36, 37，38である．すなわち現代日本人に比べて $\mathbf{M}_{\mathbf{1}}$ では $\mathbf{Y}_{\mathbf{5}}$ がやや多く， $\mathrm{M}_{\mathbf{2}}$ では+ ${ }_{4}$ の出現率は広田弥生式人の方が 多くそれ対して+5が少なくなっている，Maにおいて は大差はないようである。 


\begin{tabular}{|c|c|c|c|c|c|c|c|c|c|c|c|c|}
\hline & \multicolumn{4}{|c|}{$\mathbf{M}_{1}$} & \multicolumn{4}{|c|}{$\mathbf{M}_{2}$} & \multicolumn{4}{|c|}{$\mathbf{M}_{\mathbf{3}}$} \\
\hline & $\mathrm{N}$ & $\mathrm{Y}$ & + & $\mathbf{X}$ & $\mathbf{N}$ & $\mathrm{Y}$ & + & $\mathrm{X}$ & $\mathbf{N}$ & $\mathbf{Y}$ & + & $\mathrm{x}$ \\
\hline Dutchmen (J $\Phi$ RGENSEN) & 1301 & 72.9 & 16.4 & 10.8 & 1334 & 18.9 & 26.0 & 55.2 & 913 & 11.1 & 11.1 & 77.9 \\
\hline Danes (J $\emptyset$ RGENSEN) & 293 & 69.3 & 13. 0 & 17.8 & 428 & 17.6 & 23.9 & 56.5 & 278 & 9.3 & 16.6 & 74.2 \\
\hline アメリカ白人 （武 久） & 57 & 29.8 & 59.7 & 10.5 & 57 & & 42.1 & 57.9 & & & & \\
\hline 日本人 $(" \prime \prime)$ & 125 & 66.4 & 32.8 & 0.8 & 125 & 1.6 & 58.4 & 40.0 & & & & \\
\hline (鈴木, 酒井) & 392 & 70.7 & 22.7 & 6.6 & 353 & 4.5 & 44.2 & 51.3 & & & & \\
\hline （中 村） & 3934 & 64.5 & 33.2 & 2.3 & 3810 & 3.8 & 71.6 & 24.6 & 114 & 1.8 & 47.4 & 50.9 \\
\hline " ～（小 住） & 1736 & 63.7 & 36. I & 0.2 & 1130 & 3.5 & 87.6 & 8.9 & 99 & 1.0 & 67.7 & 31.3 \\
\hline $\begin{array}{r}\text { 広田遺跡弥生式時代人 } \\
\text { (山田, 中川) }\end{array}$ & 130 & 73.8 & 26.2 & & 135 & 5.2 & 83. 0 & 11.9 & 68 & 4.4 & 47.1 & 48.5 \\
\hline
\end{tabular}

下顎大臼歯の咬頭と溝型との関係

\begin{tabular}{|c|c|c|c|c|c|c|c|c|}
\hline & & & $\mathrm{Y}_{5}$ & $\mathbf{Y}_{4}$ & +5 & +4 & $\mathrm{X}_{5}$ & $\mathrm{X}_{4}$ \\
\hline \multirow{3}{*}{$\mathrm{M}_{1}$} & $\mathbf{R}$ & $\%$ & $\begin{array}{c}43 \\
66.15 \pm 5.86\end{array}$ & $\begin{array}{c}2 \\
3.08 \pm 2.14\end{array}$ & $\begin{array}{c}18 \\
27.69 \pm 5.55\end{array}$ & $\begin{array}{c}2 \\
3.08 \pm 2.14\end{array}$ & & \\
\hline & L & $\%$ & $\begin{array}{c}48 \\
73.84 \pm 5.45\end{array}$ & $\begin{array}{c}2 \\
3.08 \pm 2.14\end{array}$ & $\begin{array}{c}14 \\
21.53 \pm 5.09\end{array}$ & $\begin{array}{c}I \\
1.55 \pm 1.53\end{array}$ & & \\
\hline & 訫 & $\%$ & $\begin{array}{c}91 \\
70.00 \pm 4.01\end{array}$ & $\begin{array}{c}4 \\
3.07 \pm 1.51\end{array}$ & $\begin{array}{c}32 \\
24.61 \pm 3.77\end{array}$ & $\begin{array}{c}3 \\
2.32 \pm 1.32\end{array}$ & & \\
\hline \multirow{3}{*}{$\mathbf{M}_{2}$} & $\mathbf{R}$ & $\%$ & $\begin{array}{c}2 \\
3.17 \pm 2.20\end{array}$ & $\begin{array}{c}1 \\
1.59 \pm 1.57\end{array}$ & $\begin{array}{c}3 \\
4.76 \pm 2.68\end{array}$ & $\begin{array}{c}49 \\
77.78 \pm 5.23\end{array}$ & & $\begin{array}{c}8 \\
12.70 \pm 4.19\end{array}$ \\
\hline & $\mathbf{L}$ & $\%$ & $\begin{array}{c}3 \\
4.23 \pm 2.38\end{array}$ & $\begin{array}{c}1 \\
1.48 \pm 1.39\end{array}$ & $\begin{array}{c}7 \\
9.86 \pm 3.53\end{array}$ & $\begin{array}{c}52 \\
73.23 \pm 5.25\end{array}$ & $\begin{array}{c}3 \\
4.23 \pm 2.38\end{array}$ & $\begin{array}{c}5 \\
7.04 \pm 3.03\end{array}$ \\
\hline & 計 & $\%$ & $\begin{array}{c}5 \\
3.73 \pm 1.63\end{array}$ & $\begin{array}{c}2 \\
1.49 \pm 1.04\end{array}$ & $\begin{array}{c}10 \\
7.46 \pm 2.20\end{array}$ & $\begin{array}{c}101 \\
75.37 \pm 3.72\end{array}$ & $\begin{array}{c}3 \\
2.24 \pm 4.04\end{array}$ & $\begin{array}{c}13 \\
9.71 \pm 2.55\end{array}$ \\
\hline \multirow{3}{*}{$\mathrm{M}_{3}$} & $\mathbf{R}$ & $\%$ & & & $\begin{array}{c}3 \\
9.09 \pm 2.94\end{array}$ & $\begin{array}{c}14 \\
42.42 \pm 8.60\end{array}$ & $\begin{array}{c}2 \\
6.07 \pm 4.15\end{array}$ & $\begin{array}{c}14 \\
42.42 \pm 8.60\end{array}$ \\
\hline & $\mathrm{L}$ & $\%$ & $\begin{array}{c}2 \\
5.71 \pm 3.92\end{array}$ & $\begin{array}{c}1 \\
2.86 \pm 2.81\end{array}$ & $\begin{array}{c}4 \\
11.43 \pm 8.91\end{array}$ & $\begin{array}{c}11 \\
31.43 \pm 7.84\end{array}$ & $\begin{array}{c}4 \\
11.43 \pm 8.91\end{array}$ & $\begin{array}{c}13 \\
37.14 \pm 8.16\end{array}$ \\
\hline & 計 & $\mathscr{6}$ & $\begin{array}{c}2 \\
2.92 \pm 2.05\end{array}$ & $\begin{array}{c}1 \\
1.47 \pm 1.45\end{array}$ & $\begin{array}{c}7 \\
10.29 \pm 3.68\end{array}$ & $\begin{array}{c}25 \\
36.76 \pm 1.84\end{array}$ & $\begin{array}{c}6 \\
8.82 \pm 3.43\end{array}$ & $\begin{array}{c}27 \\
39.71 \pm 5.93\end{array}$ \\
\hline
\end{tabular}


下顎第1大曰雪に於ける咬頭数及び溝型の各人種別出現頻度比較

\begin{tabular}{|c|c|c|c|c|c|c|c|c|c|}
\hline \multirow[t]{2}{*}{ 人 種別 } & \multirow{2}{*}{$\begin{array}{l}\text { 調 } \\
\text { 查 } \\
\text { 歯 } \\
\text { 数 }\end{array}$} & \multirow{2}{*}{$Y_{5}$} & \multirow{2}{*}{$\mathrm{Y}_{4}$} & \multirow{2}{*}{+5} & \multirow{2}{*}{+4} & \multicolumn{2}{|c|}{ 清 型 } & \multicolumn{2}{|c|}{ 㕮 頭 数 } \\
\hline & & & & & & $\mathbf{Y}$ & + & 5 & 4 \\
\hline Australians (HELLMAN) & 18 & 100.0 & & . & & 100.0 & & 100.0 & \\
\hline Buriat Mongols (HELLMAN) & 36 & 100.0 & & & & 100.0 & & 100.0 & \\
\hline Eskimos (HELLMAN) & 29 & 97.0 & & 3. 0 & & 97.0 & 3. 0 & 100.0 & \\
\hline West African Negroes (HELLMAN) & 97 & 99.0 & 1.0 & & & 100.0 & & 99.0 & 1.0 \\
\hline Modern Dutchmen (right) (J $\Phi$ RGENSEN) & 832 & 61.2 & 7.7 & 27.4 & 3.7 & 69.2 & 30.8 & 89. 4 & 10.6 \\
\hline$" \quad($ left $) \quad(\mathrm{J} \Phi$ RGENSEN $)$ & 792 & 67.4 & 8.6 & 20.0 & 4.0 & 76.5 & 23.5 & 89.8 & 10.2 \\
\hline Medieval Danes (right) (JøRGENSEN) & 150 & 60.7 & 3. 7 & 34.1 & 1.5 & 69.4 & 30.6 & 95.1 & 4.9 \\
\hline$" \quad($ left $) \quad(\mathrm{J} \Phi$ RGENSEN $)$ & 150 & 65.0 & 2.2 & 32.8 & & 69.2 & 30.8 & 97.9 & 2.1 \\
\hline 人 （鈴木, 酒井） & 392 & 69.9 & 0.8 & 28. 1 & 1.3 & 70.7 & 29.3 & 97.9 & 2.1 \\
\hline 人 （中 村） & 3934 & 62.8 & 1.7 & 31.4 & 4.1 & 64.5 & 35.5 & 94.2 & 5.8 \\
\hline 人 （小 住） & 1736 & 63.3 & 0.5 & 32.4 & 3.9 & 63.7 & 36.3 & 95.6 & 4.4 \\
\hline 広 田 弥 生 式 時 代 人 & 131 & 70.0 & 3.1 & 24.6 & 2.3 & 73.8 & 26.2 & 94.7 & 5.3 \\
\hline
\end{tabular}
表37

下顎第 2 大曰歯における咬頭数及び溝型の各人種別出現頻度比較

\begin{tabular}{|c|c|c|c|c|c|c|c|c|c|}
\hline \multirow{2}{*}{$\begin{array}{l}\text { 人 種 } \\
\text { (調 查 者) }\end{array}$} & \multirow{2}{*}{ 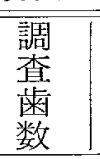 } & \multirow{2}{*}{$\mathrm{Y}_{5}$} & \multirow{2}{*}{$\mathrm{Y}_{4}$} & \multirow{2}{*}{+5} & \multirow{2}{*}{+4} & \multicolumn{2}{|c|}{ 溝型 } & \multicolumn{2}{|c|}{ 咬 頭 数 } \\
\hline & & & & & & $\mathrm{Y}$ & + & 5 & 4 \\
\hline Australians (HELLMAN) & 21 & \multirow[t]{2}{*}{ 5. } & \multirow[b]{2}{*}{5.0} & 43.0 & \multirow{2}{*}{$\begin{array}{l}52.0 \\
64.0\end{array}$} & 5.0 & S5. o & 48.0 & 52.0 \\
\hline Buriat Mongols (HELLMAN) & 39 & & & 31.0 & & 5.0 & 95.0 & \multirow{2}{*}{$\begin{array}{l}31.0 \\
43.0\end{array}$} & 69.0 \\
\hline Eskimos (HELLMAN) & 30 & 6.0 & 7.0 & 37.0 & \multirow{2}{*}{$\begin{array}{l}50.0 \\
63.0\end{array}$} & 13. 0 & 87. 0 & & 57.0 \\
\hline West African Negroes (HELLMAN) & 96 & 17.0 & 12.0 & 8.0 & & 29.0 & 71.0 & 25.0 & 75. 0 \\
\hline Modern Dutchmen (right) (JøRGENSEN) & 734 & 1.8 & 15.2 & 10.1 & 72.8 & 16.7 & 83.3 & 11.6 & 88.4 \\
\hline$" \quad($ left $)(J ø$ RGENSEN $)$ & 712 & 3.4 & 17.6 & 10.3 & 68.7 & 21.0 & 79.0 & 14.0 & 86.0 \\
\hline Medieval Danes (right) (J $\emptyset$ RGENSEN) & 217 & 0.6 & 13.5 & 9.8 & 76.1 & 14.3 & 85.7 & \multirow{2}{*}{$\begin{array}{l}10.4 \\
10.5\end{array}$} & 89.6 \\
\hline$" \quad($ left $)(\mathrm{J} \varpi \mathrm{RGENSEN})$ & 212 & 1.9 & 18.5 & 8.6 & 71.0 & 20.9 & 79. 1 & & 89.5 \\
\hline 本 人 (鈴木, 酒井) & 353 & 2.6 & 2.0 & 51.3 & 44.2 & 4.5 & 95.5 & 53.7 & 46.3 \\
\hline 人（中 村） & 3810 & 2.3 & 1.5 & 39.6 & 56.6 & 3.8 & 96.2 & 41.9 & 58.3 \\
\hline 日 本少 (小住) & 1132 & 2.5 & 0.9 & 39.9 & 56.7 & 3.5 & 96.5 & \multirow{2}{*}{$\begin{array}{l}42.3 \\
13.4\end{array}$} & 57.7 \\
\hline 広 田 弥 生 式 時 代人 & 135 & 3.7 & 1.5 & 9.7 & 85.1 & 5.2 & 94.8 & & 86.6 \\
\hline \multicolumn{10}{|c|}{ 表38 下顎第 3大曰歯におりる咬頭数及び溝型の各人種別出現頻度比較 } \\
\hline & 調 & \multirow[b]{2}{*}{$\mathrm{Y}_{5}$} & \multirow[b]{2}{*}{$\mathrm{Y}_{4}$} & \multirow[b]{2}{*}{+5} & \multirow[b]{2}{*}{+1} & 溝 & 型 & \multicolumn{2}{|c|}{ 咬 頭 数 } \\
\hline & 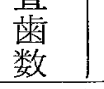 & & & & & $\mathrm{Y}$ & + & 5 & 4 \\
\hline & 23 & \multirow[t]{3}{*}{14.0} & & 72.0 & 14.0 & 14.0 & 86.0 & 860 & 14.0 \\
\hline Buriat Mongols (HELLMAN) & 31 & & & 77.0 & 23.0 & & 100.0 & 77.0 & 23. 0 \\
\hline Eskimos (HELLMAN) & 29 & & & 52.0 & 48.0 & & 100.0 & 52.0 & 48.0 \\
\hline West African Negroes (HELLMAN) & 88 & 20.0 & 3. 0 & 59.0 & 17.0 & 23.0 & 76.0 & 79.0 & 20.0 \\
\hline Modern Dutchmen (right) (J $\emptyset$ RGENSEN) & 497 & 3.7 & 7.3 & 48.1 & 40.9 & 10.9 & 89. 1 & 52.3 & 47.7 \\
\hline$" \quad($ left $)(J \Phi$ RGENSEN $)$ & 488 & 5.0 & 6.4 & 55.0 & 33.6 & 11.2 & 88.8 & 60.6 & 39.4 \\
\hline Medieval Danes (right) (JøRGENSEN) & 145 & 6.2 & 6.2 & 54.3 & 33.3 & 11.2 & 88.8 & 59.4 & 40.6 \\
\hline$\prime \quad($ left $)(J \Phi$ RGENSEN $)$ & 137 & 3.1 & 11.5 & 51.1 & 34.4 & 7.4 & 92.6 & 58. I & 41.9 \\
\hline 人 （中 村） & 114 & 1.8 & & 49.1 & 49.1 & 1.8 & 98.2 & 50.9 & 49. 1 \\
\hline 人 （小 住） & 101 & 1.0 & & 44.4 & 54.6 & 1.0 & 99.0 & 47.5 & 52.5 \\
\hline 広 田 弥 生 式 時 代 人 & 73 & 3.0 & 1.5 & 19.1) & 76.5 & 4.4 & 95.6 & 21.9 & 78. 1 \\
\hline
\end{tabular}


下 顎 大 $⿴$ 一 歯 の 雪 根 数

\begin{tabular}{|c|c|c|c|c|c|c|}
\hline & & & 3 & 2 & 1 & 調查総数 \\
\hline \multirow{3}{*}{$M_{1}$} & $\mathbf{R}$ & $\begin{array}{l}\mathrm{N} \\
\%\end{array}$ & & $\begin{array}{c}21 \\
100.00 \pm 0\end{array}$ & & 21 \\
\hline & L & $\begin{array}{l}\mathrm{N} \\
\%\end{array}$ & $\begin{array}{c}1 \\
4.76 \pm 4.64\end{array}$ & $\begin{array}{c}20 \\
95.24 \pm 4.64\end{array}$ & & 21 \\
\hline & 計 & $\begin{array}{l}\mathrm{N} \\
\%\end{array}$ & $\begin{array}{c}1 \\
2.38 \pm 3.35\end{array}$ & $\begin{array}{c}41 \\
97.62 \pm 2.35\end{array}$ & & 42 \\
\hline \multirow{3}{*}{$\mathrm{M}_{2}$} & $\mathbf{R}$ & $\begin{array}{l}\mathrm{N} \\
96\end{array}$ & $\begin{array}{c}1 \\
6.67 \pm 6.44\end{array}$ & $\begin{array}{c}13 \\
86.66 \pm 8.77\end{array}$ & $\begin{array}{c}1 \\
6.67 \pm 6.44\end{array}$ & 15 \\
\hline & L & $\begin{array}{l}\mathrm{N} \\
\%\end{array}$ & & $\begin{array}{c}19 \\
90.48 \pm 6.40\end{array}$ & $\begin{array}{c}2 \\
9.52 \pm 6.40\end{array}$ & 21 \\
\hline & 計 & $\begin{array}{l}\mathrm{N} \\
\%\end{array}$ & $\begin{array}{c}1 \\
2.78 \pm 2.74\end{array}$ & $\begin{array}{c}32 \\
88.89 \pm 5.23\end{array}$ & $\begin{array}{c}3 \\
8.33 \pm 4.60\end{array}$ & 36 \\
\hline \multirow{3}{*}{$\mathbf{M}_{3}$} & $\mathbf{R}$ & $\begin{array}{l}\mathrm{N} \\
\%\end{array}$ & & $\begin{array}{c}10 \\
90.91 \pm 8.66\end{array}$ & $\begin{array}{c}1 \\
9.09 \pm 8.66\end{array}$ & 11 \\
\hline & $\mathbf{L}$ & $\begin{array}{l}\mathrm{N} \\
\%\end{array}$ & & $\begin{array}{c}6 \\
75.00 \pm 15.30\end{array}$ & $\begin{array}{c}2 \\
25.00 \pm 15.30\end{array}$ & 8 \\
\hline & 計 & $\begin{array}{l}\mathbf{N} \\
\%\end{array}$ & & $\begin{array}{c}16 \\
84.21 \pm 8.36\end{array}$ & $\begin{array}{c}3 \\
15.79 \pm 8.36\end{array}$ & 19 \\
\hline
\end{tabular}
下顎大臼歯の過剩結節出現頻度

\begin{tabular}{|c|c|c|c|c|c|}
\hline & & 調 査 総 数 & Protostylid & 6th Cusp & 7th Cusp \\
\hline \multirow[t]{2}{*}{$\mathbf{M}_{1}$} & $\mathbf{N}$ & \multirow{2}{*}{139} & 6 & 4 & 1 \\
\hline & 96 & & 4.3 & 2.9 & 0.7 \\
\hline \multirow[t]{2}{*}{$\mathbf{M}_{\mathbf{2}}$} & $\mathrm{N}$ & \multirow{2}{*}{143} & 2 & 3 & 3 \\
\hline & $\%$ & & 1.4 & 2.1 & 2.1 \\
\hline \multirow[t]{2}{*}{$\mathrm{M}_{3}$} & $\mathbf{N}$ & \multirow{2}{*}{79} & 2 & 2 & 0 \\
\hline & $\%$ & & 2.5 & 2.5 & 0 \\
\hline
\end{tabular}

㐘根数と桶状根について

下頢大四歯の歯根数は一般に近心根之遠心根の二根よ り構成されているが, $\mathrm{M}_{1}$ 上り $\mathrm{M}_{2}$ さらに $\mathrm{M}_{3}$ へと融合の 傾向を示し，ついには単根となるものである。そしてそ の融合の場合完全に単根性になりえないところの移行型 として，頓側半部が先に融合して舌側半部がいまだ融合 に台らない状態のいわゆる樋状根というあのが認められ
るのである。また時には三根性の歯牙を認めることああ る。広田弥生式人については表39に示すごとく $\mathbf{M}_{\mathbf{1}}$ では 2 根が97.6\%で1根はなく3 根は1 例認められた。現代 日本人では 3 根が20\%（藤田）, $28 \%$ (上条) とかなり多 く認められるのに対して広田弥生式人については少ない ようである。 $\mathrm{M}_{2}$ では 2 根が88.9\%，1 根が8.3\%である が，I根の中で桶状根は $5.6 \%$ で現代日本人の場合 I根 
が30\%でしかもその全部が樋状根である（中山）上いう のに比べると, 広田弥生式人の菡根は融合傾向が扰くれ ているといいうる。.Maでは 2 根が84.2\%，1 根が15.8 \%でその中樋状根はほとんどないが，現代日本人では1 根が約 $30 \%$ その中樋状根は $5.3 \%$ \%であるのに比べると1 根性の蒾牙はやはり少ない.

過剩結節の出現状態

Protostylid の出現率は表40のどとく非常に少なく， 特にM1 に多く認められるといわれているが，現代日本 人では山田等9)の全 $12 \%$, ㅇ $9 \%$, 酒井18)の $10.8 \%$, 住 谷1908.1\%に比して少ない.

第6 咬頭之は遠心辺縁隆線の付近にみられるものであ るが, 表40に示すごとき出現率で現代日本人では山田等 9) の $\mathbf{M}_{1}$ の占14.6\%, 우10.2\%, $\mathbf{M}_{2}$ の占17.3\%, 우12\% また中村15)の $\mathrm{M}_{1} 17.4 \%, \mathrm{M}_{2} 17.6 \% ， \mathrm{M}_{3} 20.2 \%$ ，鈴木 等17)0 $\mathbf{M}_{1} 12.5 \% ， \mathbf{M}_{2} 3.7 \%$ などに比して非常に少ない.

第 7 咬頭とは舌側の二咬頭すなわち Metaconid と Entoconid との間に介在する小結節であるが表40ので とくきわめて少ない．現代日本人では鈴木等17)の $\mathbf{M}_{1} 5.7$

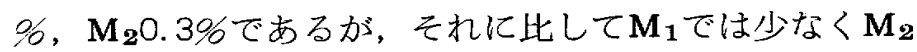
ではやや多いようである.

\section{IV. 総括ならびに考察}

（1）咬粍ならびにう歯について

咬粍度については年令が不確実なためはっきりしたて とはわからないが，上下顎とも0 度より 2 度までのもの がそれぞれ63\%抢よび60\%で，3〜4度のものは少なく なっているとてろから，それほどの老年層とは考えられ ない，当時の食生活等を考慮すれば現代人の咬粍度とは 一様に考えられないだろうから，広田遺跡の弥生式人は 若年層より中年層のものではなかろうか.

う雨の出現頻度もこれまた適格な判定を下すことは困 難であるが現代人に比較する上少ないように思われる。 しかしう蒾に䍜患して歯がなくなっているあのああると 思われるし，また遊離した函では特に残根などの場合に は失われているものもあるだろうし，断定的なことはい えない.

（2）歯の計測值よりみた特徽について

上顎前歯は現代日本人に比べて歯冠の長さと幅が小さ く, 歯根の長さと歯の全長ならびに歯冠の厚さは大きい ということがいえる。下顎邻歯は歯冠の幅が小さくその 他はいずれも大きい傾问が認められる，上顎小歯は雬 根の長さおよび雷の全長は大きいがその他は小さい．下 顎小曰蒾は曾冠の幅と厚さが小さくその他の各径は大き
い. 上顎大曰歯は歯冠の幅が小さくその他では大きな差 は認められない，下顎大臼歯は歯冠の幅が小さくその他 は大きい。

すなわち広田遺䟢より発掘せられた弥生式人の函は現 代日本人に比べて一般に長径特に歯根長が長く幅径が小 さい．乙のととは顎骨に対して雪根が樑く入り骨植を堅 固にしていることになり，当時の食生活その他の環境に 順応した結果であろう。

またほぼ同時代の土井ケ浜弥生式人に比べる上米冠の 長さは一般に大きく, 歯冠の幅や厚さは小さいが, 雪根の 長さや歯の全長については各歯別によって区々である. 三津弥生式人に比べると上下顎犬瞇が小さいことが特徴 的である。その他の歯であ歯冠の長さを除いては各歯之 も一般に小さい。すなわち同時代人の間に拁いては地方 差が認められるようである。

(3) 前䨑形態の特徽について

上顎切歯に求けるシャベル型切歯の出現状態は現代日 本人に比較して少ないが，白人や黒人に此べると多い． 埴原10)によるとこの形質はモンゴロイド系の人種に特徽 的なものであり，したがって日本人にあ当然多いとして いる。しかしながら弥生式時代人に少ないということは いかなる原因によるあのか判明しない，あるいはモンゴ ロイド系以外の人種に属するあのであったかむしれない 度，ただこれだけの歯の形質によって推測することはで 声ない，但し現代日本人や他のモンゴロイド系人種より は少ないが，それ以外の人種に比較すれば勿論多いので あって，特に側切歯ではこの形質がかなり強く出現して おり，やはり現代日本人ほどではないがある程度のモン ゴロイド的形質を持っているもの之も考えられる。

基底結節や棘突起については現代日本人と大差はない あの上思われる. 斜切痕は_上顎の切歯特に側切歯に多く 現われるあのであるが，垷代日本人に比べるとその出現 頻度が少なく，また旨孔の出現頻度屯現代日本人に比心 て少ない，上下顎側切䨑の犬雬化の傾向は下䫟では現代 日本人と変りないが上顎では著しく少ない，すなわち斜 切痕，盲孔书よび上顎側切歯の犬歯化といったものは蒾 の進化過程に打ける退化的形質であると考えられるが， これらがいずれあ弥生式時代人上りあ現代人が多くの出 現率を示していることは時代的な差異に基く㐘の形質退 化の現象之みてよいだろう。しかもすべて上顎歯で特に 側切歯にそのような事実が認められるということは注目 すべき点である.

(4) 小臼歯形態の特徽について

上顎小臼歯については咬合面の溝の形態が現代日本人 


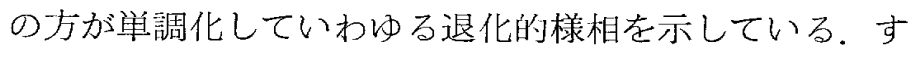
なわち溝型は最む基本的な $\mathrm{A}$ 型が特に $\mathrm{P}_{\mathbf{1}}$ に多くみられ るのである，また根数でも $\mathrm{P}_{\mathbf{1}}$ に㧈いては現代日本人より 屯二根性のものが多いことから，広田弥生式人は特に $\mathrm{P}_{\mathbf{1}}$ に执いて現代日本人よりも原始的形態を示している といい得る。

下顎小曰曾については咬頭型は $\mathrm{P}_{1}$ では現代人と大き な差はないが， $\mathrm{P}_{2}$ では差異が認められる。これを 2 咬

表4 I 下顎小臼歯の咬頭数比較

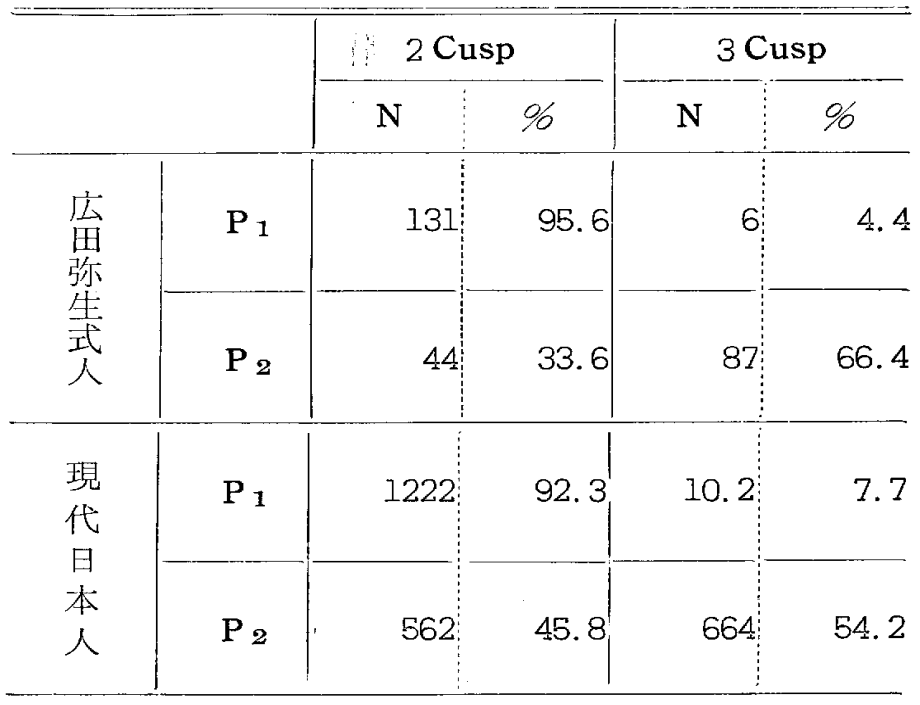

頭歯と 3 咬頭歯の二つにしぼってみると表 41 二でとく広 田弥生式人の方が現代日本人に比べて $\mathrm{P}_{1}$ ではわずかな がら 2 咬頭霜の出現率が高くなって抢り， $\mathrm{P}_{2}$ では反対 に3咬頭霆が多くなっている，次に咬合面の溝の型は $\mathrm{P}_{1}$ では $\mathrm{E}$ 型が大部分をしめて現代日本人之大差はない が， $\mathrm{P}_{2}$ ではA型が多くこの点現代日本人のC型が多い の之は異っている。咬頭の変化と溝型とは相互に関連性 があることを考え合せると，下顩小田歯 部では $\mathrm{P}_{\mathbf{1}}$ より 屯 $\mathbf{P}_{\mathbf{2}}$ に時代的形態変化の推移がみられるようである.

（5）上顎大曰歯の形態的特徵について

上顎大曰蒾の咬頭は原則として 4 咬頭であるが，進化 の過程で咬頭数が退化減少してくる。 その場合最も退化 の著しいのは Hypocone であり, 次で Metacone であ る. 広田弥生式人は現代日本人に比べて Hypocone の退 化傾向が抢くれていることが認められる，特に $\mathrm{M}_{\mathbf{1}}$ では Hypocone の退化したものは全くなく，また $\mathrm{M}_{2}$ でも現 代日本人に比べて 4 咬頭性を保持しているものが多い.

次に上顎大曰歯では歯冠が強く近遠心的方向上り圧平 されて，咬合面外形が本来の菱形的なもの加ら煩舌的に 細長い四辺形に変ってくる場合がある。乙れも一種の退 化的特質と考えられるが，との点はむしろ広田弥生式人
の方が現代日本人より多くみられるようである。

歯根の融合傾向は現代日本人と大差はないようであ る.

（6）下顎大曰歯の形態的特徵について

咬頭数は $M_{1}$ は 5 咬頭, $M_{2}$ と $M_{3}$ では 4 咬頭が大部分 をしわており，乙の点 $\mathrm{M}_{1}$ については現代日本人と大差 なきむ $\mathbf{M}_{\mathbf{2}}$ および $\mathbf{M}_{3}$ につては 4 咬頭歯が非常に多いと いうことが特徵的である。一般に大曰歯部に扔いては 咬頭数は $\mathrm{M}_{1}$ より $\mathrm{M}_{2}$ 更に $\mathrm{M}_{3}$ へ之減少していく傾向にあ り，その際 Hypoconulid が消失するのが原則である。 広田弥生式人の場合は $\mathbf{M}_{\mathbf{1}}$ より $\mathbf{M}_{\mathbf{2}}$ になって急激に 4 咬頭 が多くなっている点がどのような要因に基くものか判断 し難いが，同じく弥生式人の三津抢よび土井ヶ浜に怙い てもこれほどの差は認められないととより考えて広田弥 生式人に特殊的な形態特質ではなからうか.

咬合面瑇の形態に関してはY型より+およびXの各型 へと退化していくのであるが， $\mathrm{M}_{1}$ ではY型， $\mathrm{M}_{2}$ では+ 型， $\mathbf{M}_{3}$ ではX型が最も多く，ての点現代日本人です打 よそ同様な傾向をみせているが， $\mathbf{M}_{\mathbf{1}}$ では $\mathrm{Y}$ 型が現代日 本人に少なく， $\mathbf{M}_{\mathbf{2}}$ では+型がやや減少しその分 $\mathrm{X}$ 型が 増加しており，溝型よりみて広田弥生式人よりあ圐代日 本人の方がやや退化傾向を示している.

次に以上の咬頭数と溝の形態について Gregory は化 石猿類である Dryopithecus の下顎大臼歯の咬合面が 5 咬頭で溝型が $\mathrm{Y}$ 型をしていることから，これを Dryopithecus Pattern と称し, 人類下顎大曰歯咬合面の基本 的形態上したが，現代人ではこの原始的形態より退化が みられ形態に変化が認められている。すなおち $\mathrm{Y}$ すが最 あ原始的な形態で $\mathrm{X}_{4}$ が最も退化した形態ということがで きる。広田弥生式人に扔いては $\mathbf{M}_{1}$ では $\mathrm{Y}_{5}, \mathbf{M}_{\mathbf{2}}$ では+4, $\mathrm{M}_{3}$ では $\mathrm{X}_{4}$ 次で ${ }_{4}$ が多く, 現代日本人と比較して大き な差異はないが， $\mathrm{M}_{1}$ に関してはY 5 の出現率は現代日本 人の方が少なくなっていることから，広田弥生式人ょり 現代日本人へと多少の退化は認められる。

歯根数は 2 根より1 根へ之融合退化の傾向があるが， 広田弥生式人は $\mathrm{M}_{2}$ 抢よび $\mathrm{M}_{3}$ に扔いて比較的 2 根のもの が多く，現代日本人よりも融合傾向は少ないように見受

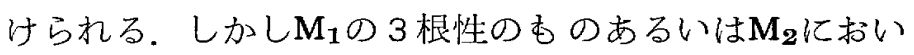
て現代人によくみられる樋状根というあのが少なく，し たがって広田弥生式人の菡根に関しては 2 根性の下顎大 曰菌として比較的安定した状態を保持して, 大きな形態 変化を示さないものと考えられる。

下顎大曰歯にみられる過剩結節については特に人類学 的に問題にされれているものとして Protostylid, 6th 
Cusp および 7th Cusp の出現頻度を調べた結果，いず れ屯広田弥生式人は現代日本人に比へて少ない，特に Protostylid は Dahlberg が Pima Indian 亿扔いて31 \%の出現率があるというととで原始的形質として系統発 生学的に意義づけている。 また6th Cusp と7th Cusp に ついてす埴原等は蒙古系人種の乳霜に多く発現すること 加ら，蒙古系人種に特徴的にみられる形質であると述心 ているが，今回の調查では広田弥生式人にはこれらの形 質は少ない。しかし蒙古系以外の人種に比べるとやや多 いようである。

\section{$\mathrm{V}$ 結 論}

広田遺跡上り出土した弥生式時代人の歯牙について当 時の人々の茵の形態的特徵を知り, '更に現代日本人の歯 牙形態との比較に打いて時代的形態の推移を知ることを 目的として調查を行なった結果を要約すると以下のごを くである.

（1）う歯は現代人に比べると少ないあのと考えられ る.

（2）咬耗度の状態からみて今回調査された広田弥生 式人は比較的に若年層より中年層に加けての年命構成で はないかと思われる。

（3）雷の大きさについては現代人に比べて長径特に 歯根長径は非常に長く，それに対して歯冠の幅は小さく なっている。

(4) 前歯のいわゆるシャベル型切歯の出現は特に上 顎中切霆に执いて現代日本人よりも著しく少ない。

（5）上顎側切雷の退化的形態の特質とみられている 盲孔，斜切痕抢よび犬雬化の傾向は現代日本人に比べて 少ない.すなわちかなりの原始的形質を示している.

（6）上顎小曰歯では咬合面の洅型あるいは歯根の状 態などより考えて特に第 I小臼歯は現代日本人よりも比 較的に原始的形態を示している。

（7）下顎小田歯は咬頭および咬合面の清型の状態か ら判断して，第1小臼崡よりも第 2 小曰歯においてょり 多くの時代差による形態変化を示しているようである.

（8）上枵大臼歯は咬頭の退化が第 1 大田雪には全く 認的られず，第 2 大臼歯においてもそれほどの退化を示 さず，現代日本人よりあ変異にそしい，また歯冠の近遠 心的圧平による形態変化は現代日本人に比べるよや多 いようで，特に第 2 大臼歯紟いて著しい。

（9）下顎大巨歯の咬頭数抢よび咬合面の溝型につい ては第1大臼歯では $\mathrm{Y}_{5}$ (Dryopithecus Pattern), 第 2 大曰歯では+4また第 3 大臼歯では $\mathbf{X}_{4}$ が最も多く，現代
日本人之比べてわずかに第1大日歯で $\mathrm{Y}_{5}$ が多い程度 で，その他では大差を認めない。

（10）下顎大曰霜の蒾根数は比較的に安定した状態を 示し，過剩根あるいは樋状根のごをき退化的融合傾向を 示す状態のものは少ない。

（11）下顎大臼歯に出現する Protostylid, 6th Cusp および7th Cusp は現代日本人に比してその出現頻度が 少ない。

（12）大きさその他二三の形質については他の同時代 人と比べてある程度の地方差と思わ扎る現象が認められ る。

以上の結果からも判るように弥生式時代中期より今日 までの約 2,000 年間に抢いて，歯の形態や大きさに急激 な変化は認められないが，個々の詳細な点については上 記のようなある程度の変化もあるのであって，特に下顎 歯よりあ上顎歯において時代差之考えられる形態変化が 多く認められる，乙れらのととはその時代的環境に支配 された結果の機能的変化に基くあのが重要な部分をしめ ているものと思われる。すお吅ち人類の進化過程におけ る菡牙形態の退化的形態変異である.

稿を終るに当り本研究のため貴重な資料を提供してい ただいた九州大学医学部解剖学教室の永井昌文助教授並 びに教室員の方々に対して深甚の謝意を申し述べます。

\section{参考文 献}

1. 大野 章; 佐賀県三津遺跡出土弥生式時代人歯牙の 人類学的研究: 人類学研究, 4 (1-4), 423-462, (1957).

2. 讃井善治; 山口県土井ケ浜遺跡出土弥生式時代人柬 牙の人類学的研究: 人類学研究, 7 (3-4), 861884, (1960).

3 . 藤田宗次; 日本人永久歯の計測学的研究 : 人類学人 類遺伝学体質学論文集，19，89-144，(1932).

4. 宮原 虎; 幽牙の人類学的研究について：人類学雑 誌, 34 (3), 87-99, (1916).

5. 小住啓一; 日本人大白歯並びに第二乳臼歯歯冠の形 態学的研究: 九州歯会誌, 14 (3), 1-44, (1960).

6. 藤田恒太郎; 歯の計測瞡準について：人類学雑誌, 61 ( 1 ), 27-32, (1949).

7. 藤原 知, 藤原 宗; 兵庫県田能遺跡出土弥生式時 代人の歯牙について：人類学輯報，36，45〜 55, (1967).

8. 山田 博, 鰐石洋己, 中川三省; 人類小曰䨤々冠の 
形態学的研究 : 九州䨑会誌, $17(3-4), 1-13$, (1964).

9. 山田 博, 村上守良, 鱓石洋己, 中川三省, 住吉良 隆，中西秀和；悓代日本人下額大臼歯の原始的形質 について：九州㐘会誌，20 (2〜3)，47〜57, (1966).

10. Kazuro Hanihara; Mongoloid Dental Complex in the Deciduous Dentition : ZINRUIGAKU ZASSI, 74 ( 2), 9-20, (1966).

11. Albert A. Dahlberg; Concepts of occlusion in physical anthropology and comparative anatomy : The Journal of the American Dental Association, 4]. (5), 530-535, (1953).

12. K. D. J $\oplus$ rgensen ; The Dryopithecus Pattern in Recent Danes and Dutchmen : Journal of Dental Research, 34 ( 2), 195-208, (1955).

13. Kazuro Hanihara and Tadayoshi Minamidate ; Tuberculum accessorium mediale internum in the Human Deciduous Lower Second Molars : ZINRUIGAKU ZASSI, 73 ( 1 ), 9-19, (1965).

14. 鈴木 誠, 酒井㻟朗; 日本人上頷大曰歯の咬合面形 態一特に遠心舌側㕮頭の退化に就て：人類学雑誌, 65 ( 2), 54-60, (1956).

15. 中村光雄 ; 日本人の下顎大曰歯々冠の形態に関する 研究 : 解剖学雑誌，32 (5)，510-528，(1955).

16. 鈴木 誠, 酒井玩朗; 日本人歯牙の Dryopithecus Pattern : 人類学雑誌, 64（3 ）,87-94，(1956).
17. 鈴木 誠，酒井玩朗 ; 日本人霜牙に於ける Tuber culum accessorium mediale internum そついて: 人類学雑誌, 64 (4), 135-139, (1956).

18. 鈴木 誠, 酒井㻟朗; 日本人歯牙に於ける Protostylid について：人類学雑誌，63 (3), 81-84, (1954).

19. 住谷 靖; 日本人に抢ける㐘の異常の統計的観察： 人類学雑誌, 67 (4), 215-233, (1959).

20. 鈴木 誠, 酒井㙇朗; 日本人上顎大曰雪の㕮合面形 態一特に遠心煩側穴頭の退 化について：人類学雑 誌, 67 (4), 185-190, (1959).

21. 埴原和郎, 阪尾信義, 桑島利充; 大臼秚歯冠形質の 個体内変異一第6 咬頭抢よび Deflecting Wrinkle そついて：日本口腔科学会雑誌，13 (2), 111117, (1964).

22. 中山愛一; 人の下顎大臼㐘に於ける樋状歯根に就て : 口腔病学会雑誌, 1.5 (4)，61-67，(1941).

23. 鰐石洋己, 住吉良隆 ; 上顎中切歯の歯冠の形態学的 研究：九州霜会誌，21（3），84-86，(1967)。

24. 小金井良精; 人類学研究 (続編)， 150-360, 東大 医学部解部学教室 (東京), (1958).

25. 藤田恒太郎; 人類学先史学講座 (I) - 歯牙の人類 学, 1-76, 雄山閣 (東京), (1940)。

26. D. R. Brothwell; Dental Anthropoløgy, 2ll-234, The Macmillan Company (New York), (1963).

27. 酒井珧朗 ; シャベル型歯牙について：信州医学誌. 3, 316-320, (1954). 